\title{
Shoot tip necrosis of in vitro plant cultures: a reappraisal of possible causes and solutions
}

\author{
Jaime A. Teixeira da Silva ${ }^{1,2} \cdot$ Esmaeil Nezami-Alanagh $^{3,4} \cdot$ María E. Barreal $^{3}$ (C) Mafatlal M. Kher ${ }^{5} \cdot$ \\ Adhityo Wicaksono ${ }^{6}\left({ }^{10} \cdot\right.$ Andrea Gulyás $^{2} \cdot$ Norbert Hidvégi $^{2} \cdot$ Katalin Magyar-Tábori $^{2} \cdot$ Nóra Mendler-Drienyovszki $^{2}$.

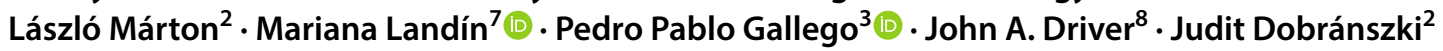

Received: 19 March 2020 / Accepted: 27 August 2020 / Published online: 3 September 2020

(c) The Author(s) 2020

\begin{abstract}
Main conclusion Shoot tip necrosis is a physiological condition that negatively impacts the growth and development of in vitro plant shoot cultures across a wide range of species.
\end{abstract}

\begin{abstract}
Shoot tip necrosis is a physiological condition and disorder that can arise in plantlets or shoots in vitro that results in death of the shoot tip. This condition, which can spread basipetally and affect the emergence of axillary shoots from buds lower down the stem, is due to the cessation of apical dominance. STN can occur at both shoot multiplication and rooting stages. One of the most common factors that cause STN is nutrient deficiency or imbalance. Moreover, the presence or absence of plant growth regulators (auxins or cytokinins) at specific developmental stages may impact STN. The cytokinin to auxin ratio within an in vitro plant can be modified by varying the concentration of cytokinins used in the culture medium. The supply of nutrients to in vitro shoots or plantlets might also affect their hormonal balance, thus modifying the occurrence of STN. High relative humidity within culture vessels and hyperhydricity are associated with STN. An adequate supply of calcium as the divalent cation $\left(\mathrm{Ca}^{2+}\right)$ can hinder STN by inhibiting the accumulation of phenolic compounds and thus programmed cell death. Moreover, the level of $\mathrm{Ca}^{2+}$ affects auxin transport and ethylene production, and higher ethylene production, which can occur as a result of high relative humidity in or poor ventilation of the in vitro culture vessel, induces STN. High relative humidity can decrease the mobility of $\mathrm{Ca}^{2+}$ within a plant, resulting in $\mathrm{Ca}^{2+}$ deficiency and STN. STN of in vitro shoots or plantlets can be halted or reversed by altering the basal medium, mainly the concentration of $\mathrm{Ca}^{2+}$, adjusting the levels of auxins or cytokinins, or modifying culture conditions. This review examines the literature related to STN, seeks to discover the associated factors and relations between them, proposes practical solutions, and attempts to better understand the mechanism(s) underlying this condition in vitro.
\end{abstract}

Keywords Boron $\cdot$ Calcium $\cdot$ Chloride $\cdot$ In vitro shoots $\cdot$ Mineral nutrient deficiency $\cdot$ Physiological disorder $\cdot$ Plant growth regulators

Communicated by Anastasios Melis.

Electronic supplementary material The online version of this article (https://doi.org/10.1007/s00425-020-03449-4) contains supplementary material, which is available to authorized users.

Jaime A. Teixeira da Silva

jaimetex@yahoo.com

$\triangle$ Adhityo Wicaksono adhitwicaksono@genbinesia.or.id; adhityo.wicaksono@gmail.com

Extended author information available on the last page of the article

\section{Introduction}

Shoot tip necrosis (STN) is a term that was originally coined by Sha et al. (1985). STN is sometimes also referred to as shoot tip abortion (Millington 1963), tip burn (McCown and Sellmer 1987), apical necrosis (AmoMarco and Lledo 1996; Koubouris and Vasilakakis 2006; Machado et al. 2014), apex necrosis (Rugini et al. 1986), top necrosis (De Klerk and ter Brugge 2011), shoot tip damage/injury (Ahmed and Palta 2017b), or shoot dieback (Barghchi and Alderson 1996). STN occurs when the shoot tip of a plant, both ex vitro and in vitro, shows 
signs of browning and death during multiplication, elongation and/or rooting stages, despite growing in apparently ideal conditions (Vieitez et al. 1989; Bairu et al. 2009b). In vitro, STN can ultimately result in the inhibited growth of the entire plantlet or it can be localized at affected shoots. The affected area spreads basipetally down from the shoot tip to lower parts of shoots. However, shoot formation from basal axillary shoot buds is not necessarily inhibited, as was observed for pistachio (Pistachia vera L.) (Barghchi and Alderson 1996). STN is also not always fatal to the plant, and apical dominance can be assumed by the next closest axillary bud, at least in sweet chestnut (Castanea sativa Mill.) and oak (Quercus robur L.) (Vieitez et al. 1989). If growing axillary branches develop STN, then a "witches' broom" pattern develops (Fig. 1; McCown and Sellmer 1987). On some occasions, the shoot tip can outgrow STN, leaving behind a scarred part of the stem with deformed leaves (McCown and Sellmer 1987). Sudha et al. (1998) observed axillary branching after STN in jivanthi (Holostemma annulare (Robx.) K. Schum., i.e., Holostemma ada-kodien Schult.) in vitro cultures. STN is problematic not only for stock cultures of in vitro plantlets, but also for commercial production (Sha et al. 1985).

The precise mechanism underlying STN still remains unclear, although some possible reasons have been proposed, including mineral deficiency or the presence of high concentrations of plant growth regulators (PGRs) in the medium. One of the most cited reasons is calcium $(\mathrm{Ca})$ deficiency. $\mathrm{Ca}$ deficiency is also a reason for the tip-burn disorder in the leaves and stems of field-grown fruits such as strawberry (Fragaria $\times$ ananassa Duchesne) and vegetables (Mason and Guttridge 1974, 1975; Saure 1998) and its symptoms closely resemble those of STN. This review aims to examine the literature that exists on this physiological disorder, including an earlier review by Bairu et al. (2009b), while exploring new literature published over the past decade. One objective is to attempt to better identify some of the possible reasons for the occurrence of STN and to suggest practical solutions to alleviate this physiological disorder in vitro.

Shoot tips are a popular explant in plant tissue culture. On occasion, shoot tip explants necrose (e.g., Krishna et al. 2008). In this review, the necrosis of shoot tip explants, i.e., explant necrosis, is not considered to be STN, which relates exclusively to the shoot tip of a tissue-cultured in vitro plantlet.

\section{Shoot tip necrosis: occurrence and alleviation}

A wide range of plants display STN in in vitro cultures (Table 1; Suppl. Table 1). Among all published studies, the occurrence of STN is particularly prominent in trees and woody shrubs (58.9\% and 21.9\%, respectively, of studies in Suppl. Table 1; Suppl. Figure 1). Studies on pistachio represent the largest proportion (10.8\%) of studies on STN in vitro, followed by pear (Pyrus spp.) (8.1\%) (Suppl. Figure 2). The incidence of STN in micropropagation, especially at the rooting stage, is shown in Fig. 2. STN, at least according to the reported literature, has occurred most frequently in the Rosaceae (20.5\%), followed by the Anacardiaceae (12.3\%) (Suppl. Figure 3). We caution readers that relative values might simply indicate the popularity of a studied species and not necessarily the actual incidence of STN in plan species or families studied to date. For example, only a single report on STN exists for an orchid, hybrid Cymbidium (Guha and Usha Rao 2012), so the incidence for the Orchidaceae is in fact $100 \%$ of studies, but the relative incidence (relative to all other species studied in Table 1) is only $1.4 \%$.

De Block (1990) found that STN was linked to Ca deficiency and associated with the use of Woody Plant Medium

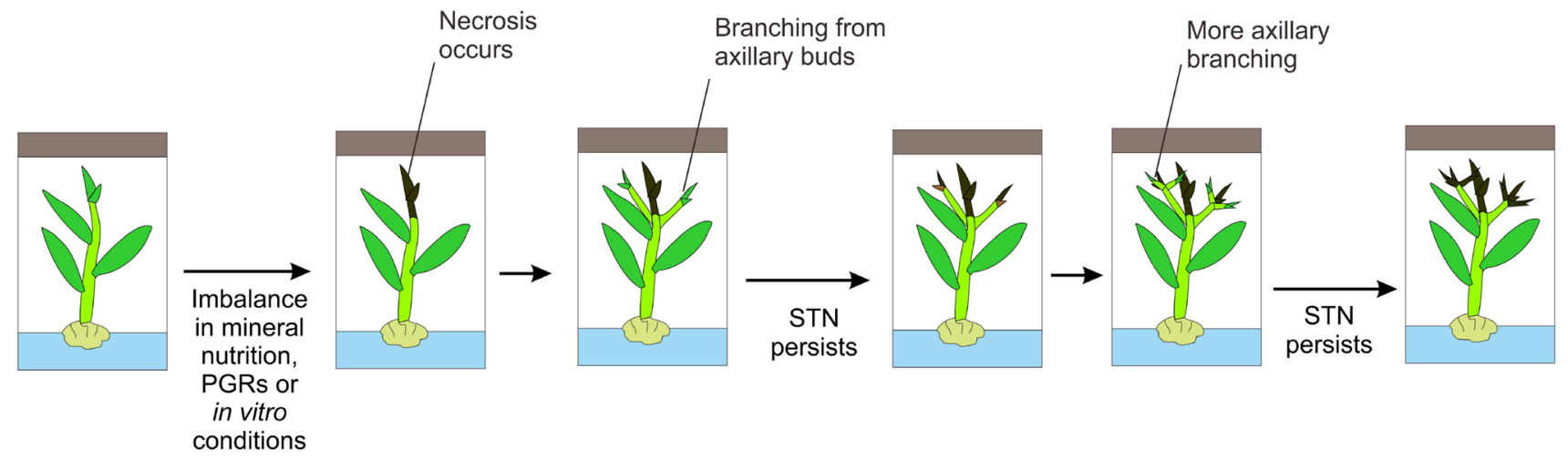

Fig. 1 Schematic diagram of shoot tip necrosis (STN). An imbalance in minerals, nutrients, plant growth regulators, or other in vitro conditions, lead to STN. This results in the blackening and death of the terminal shoot tip, the branching of axillary buds, and in some cases, STN in axillary shoots, leading to the formation of a "witches' broom" pattern 


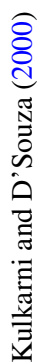

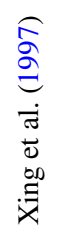

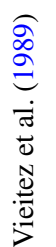

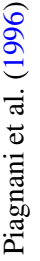

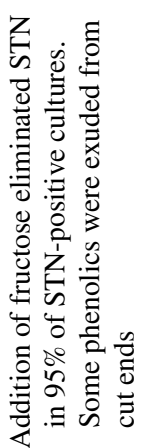

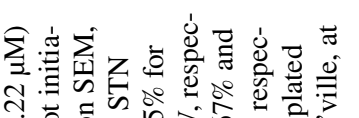

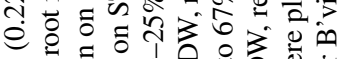

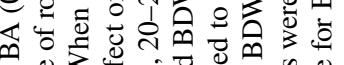

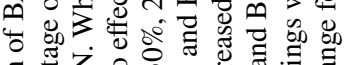

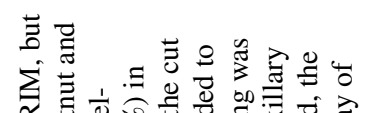

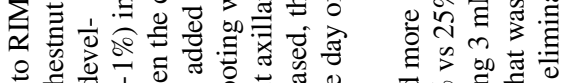

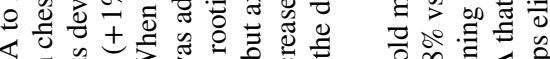

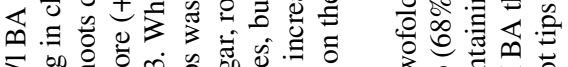

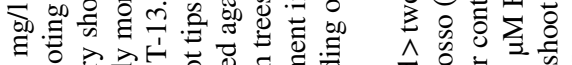

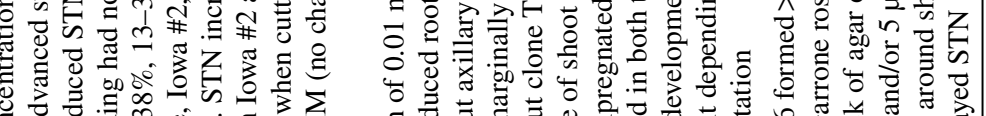

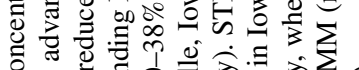

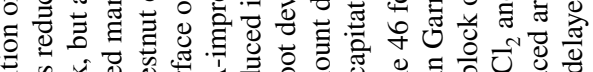

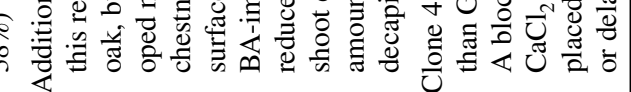
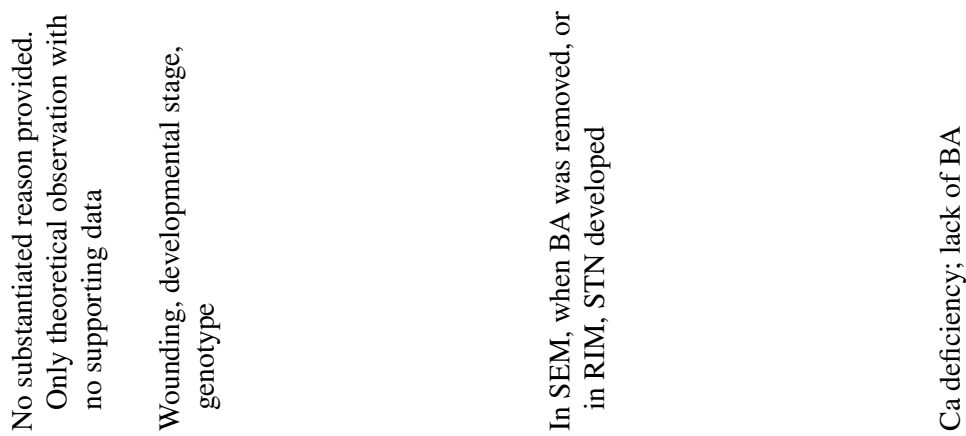

हू का

莎

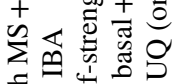

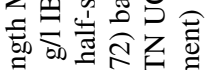

氖芯氞

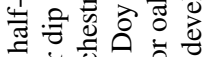

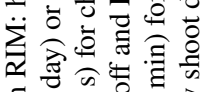

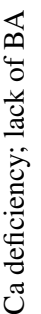

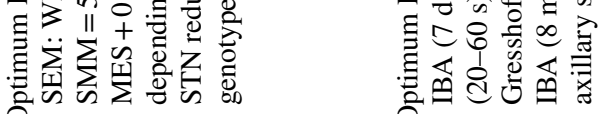

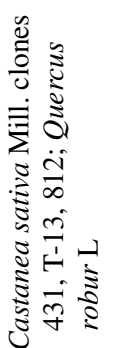

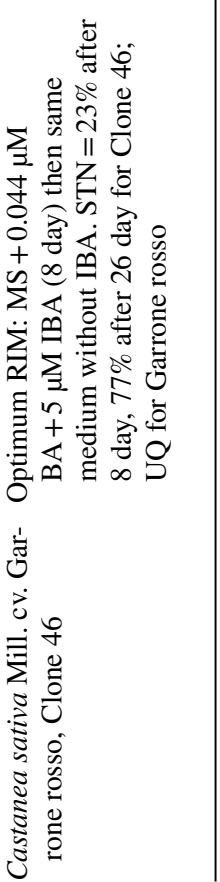




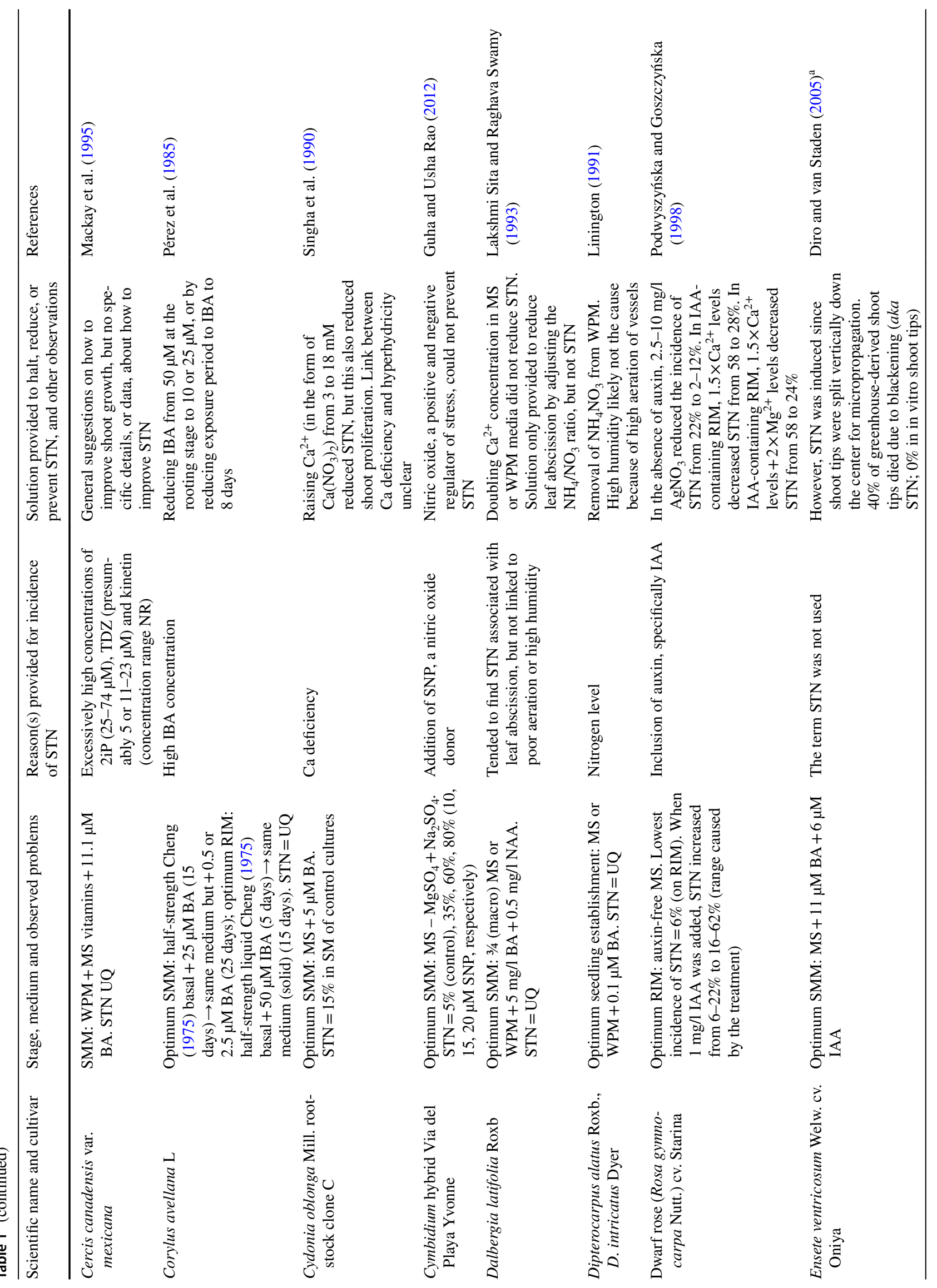




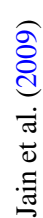

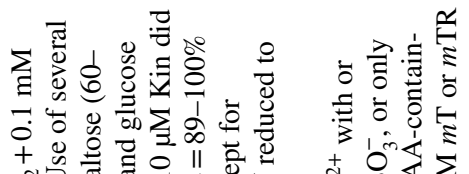

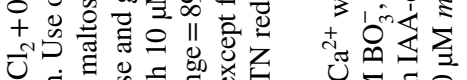

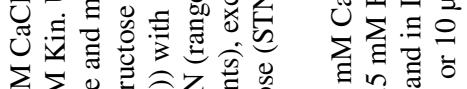

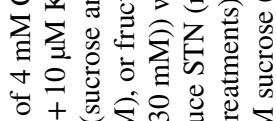

ดै?

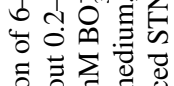

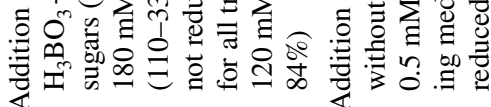

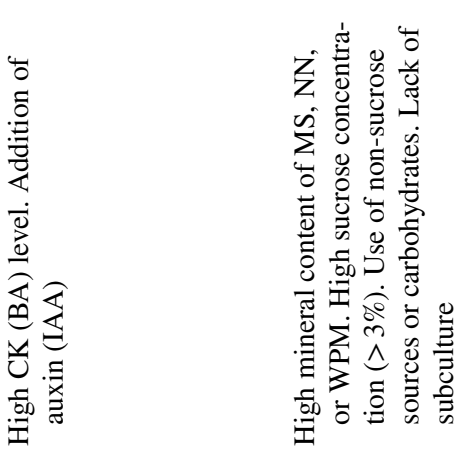

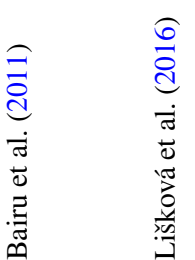
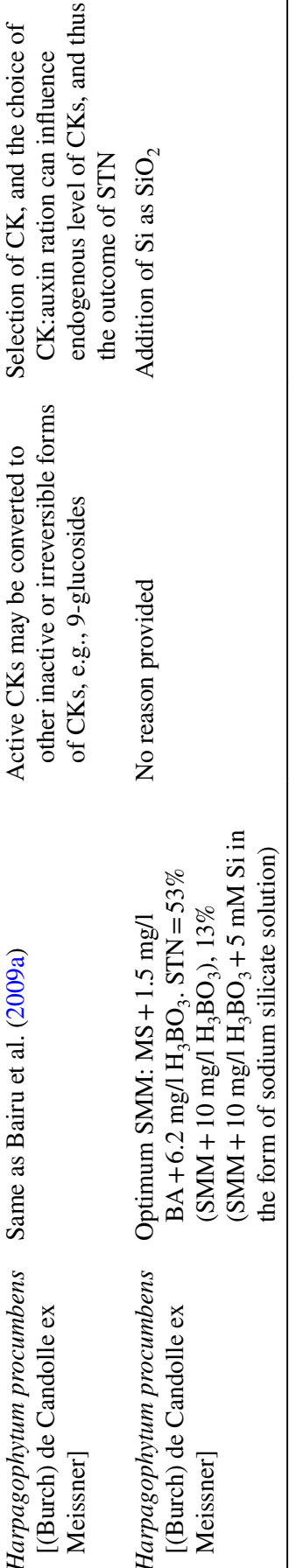


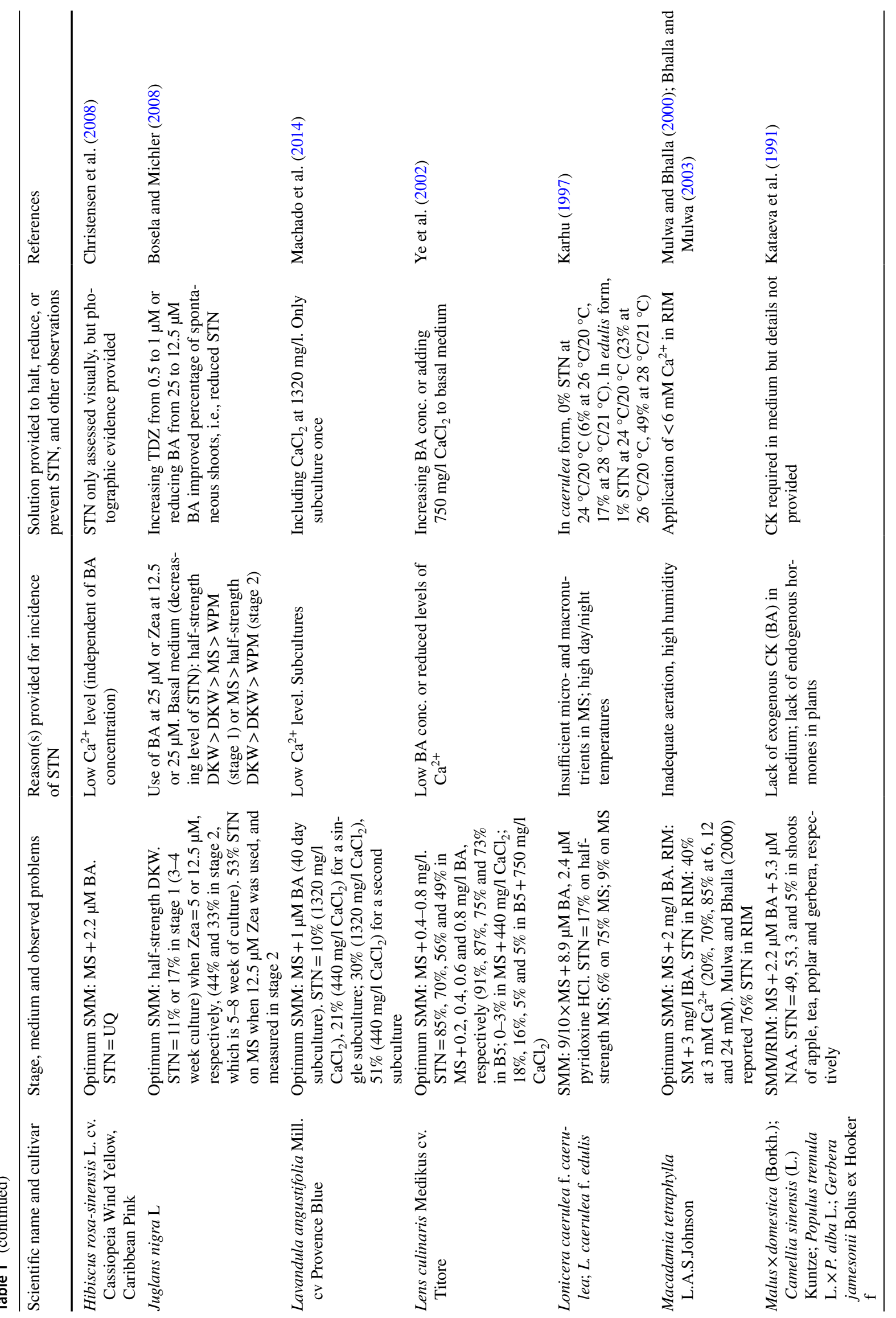




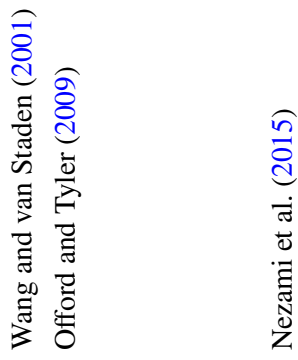

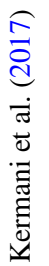

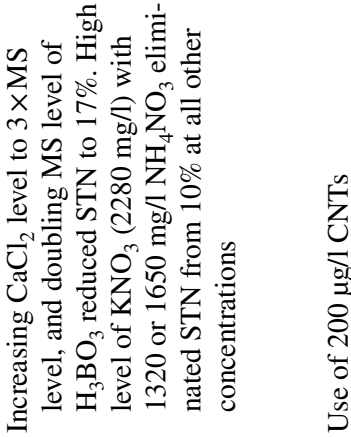

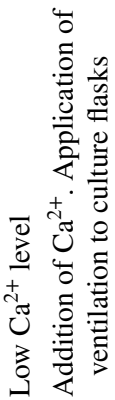

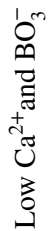

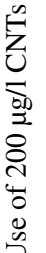

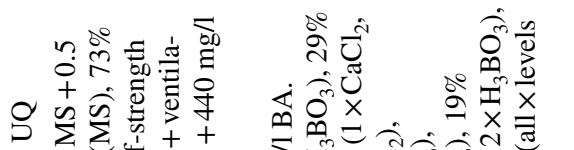

Z

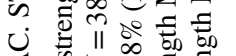

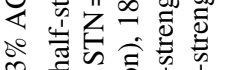

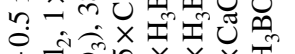

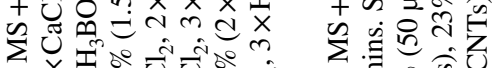

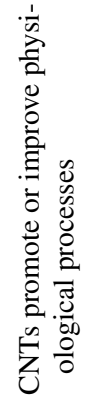

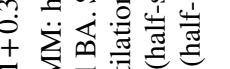

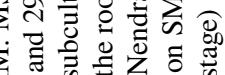

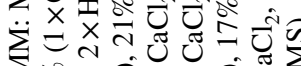

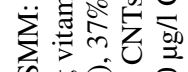

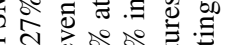

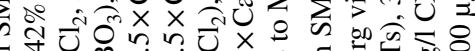

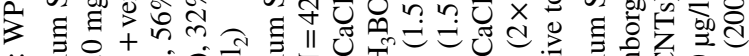

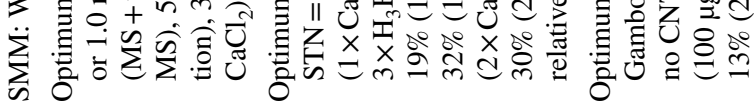

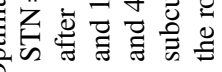

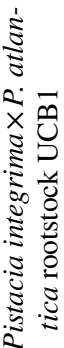

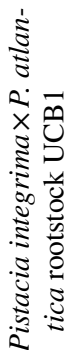




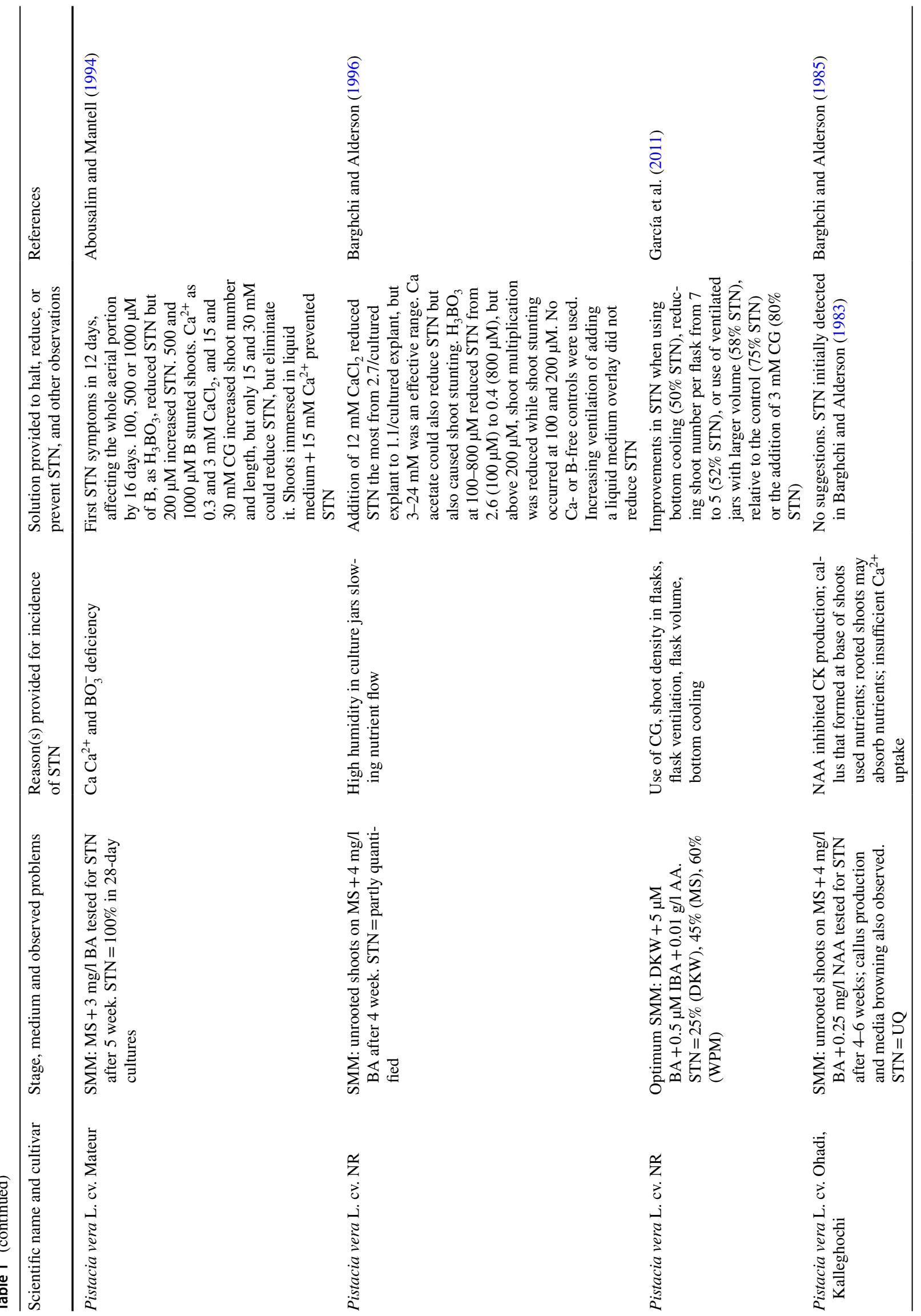




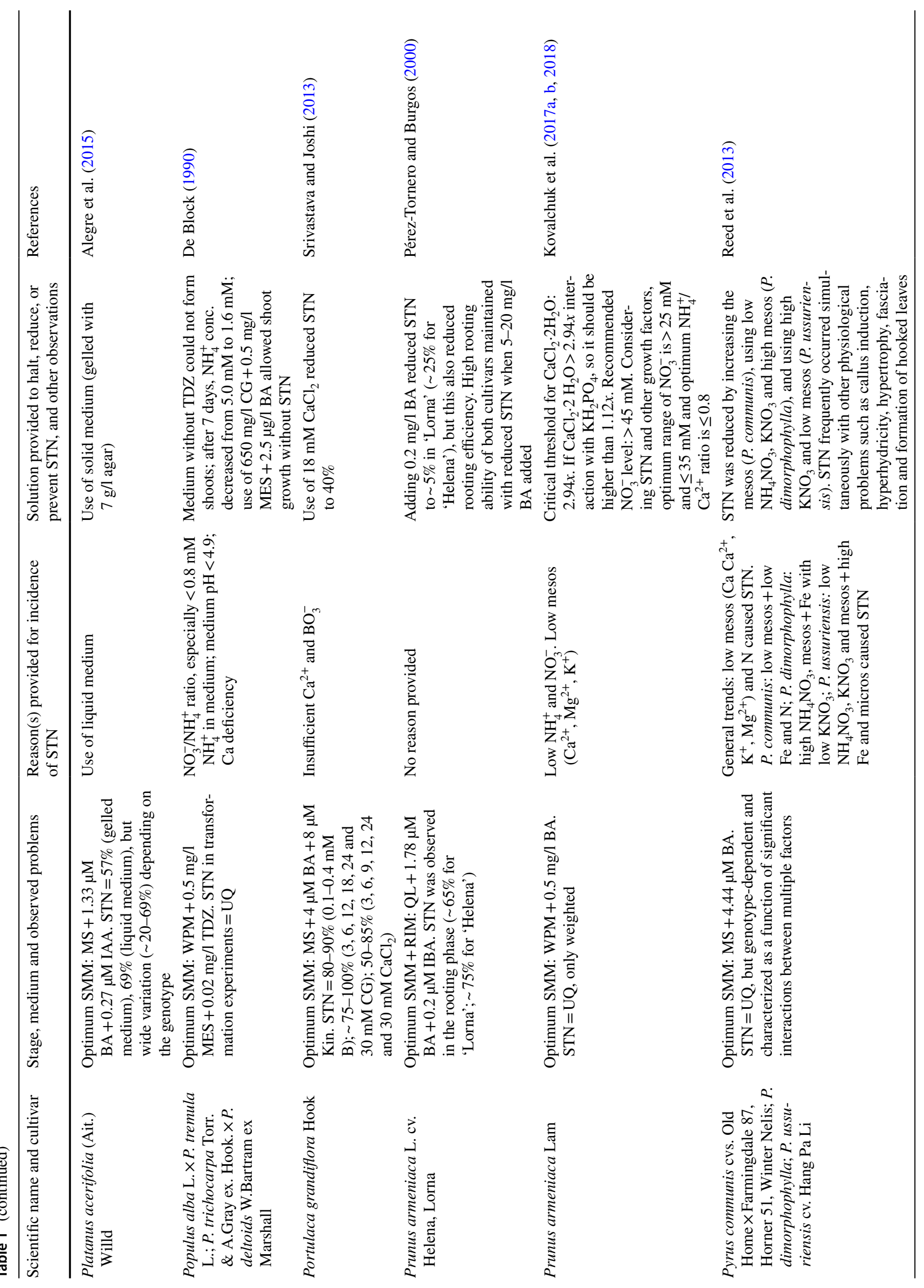




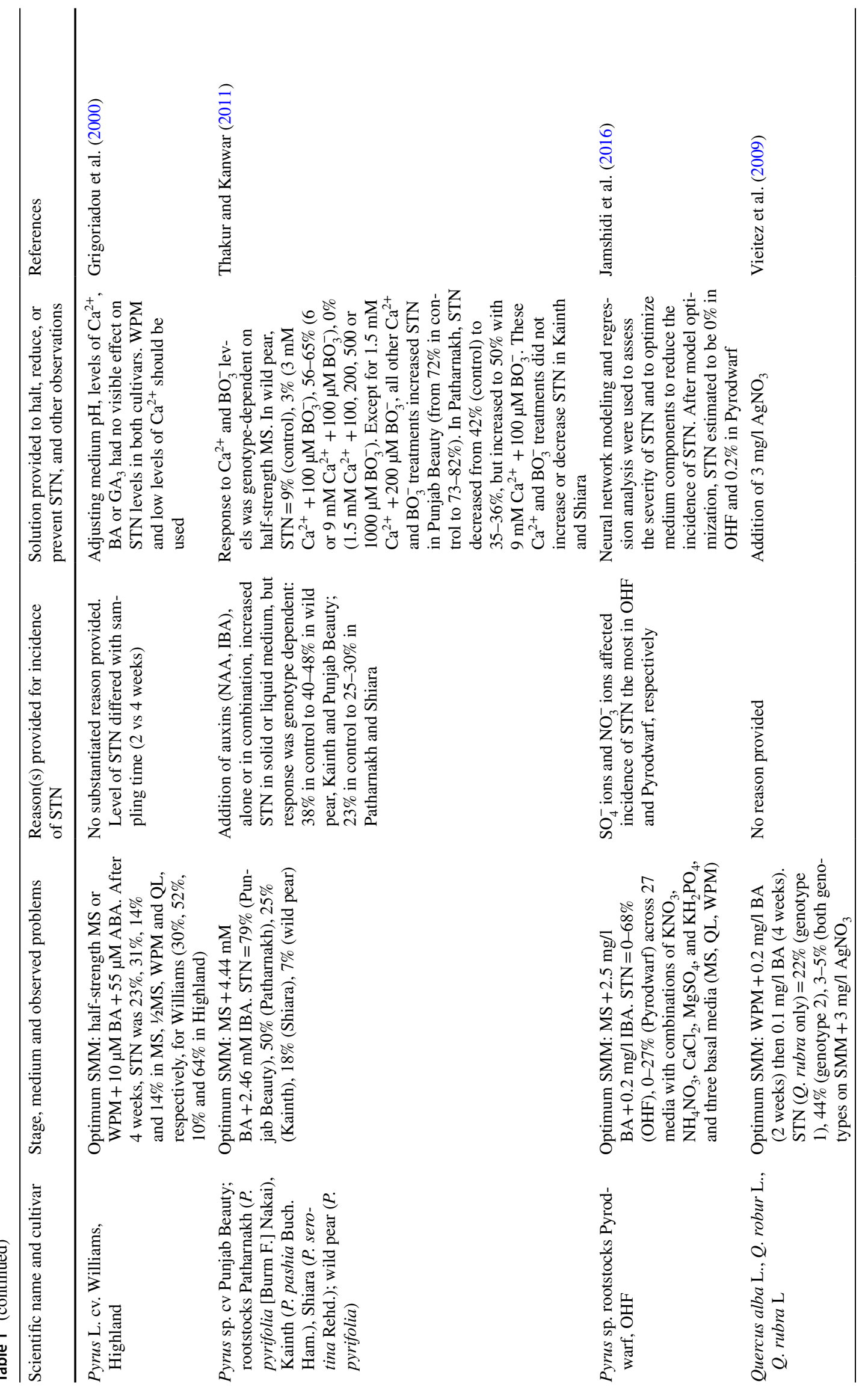




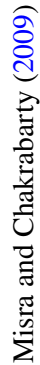

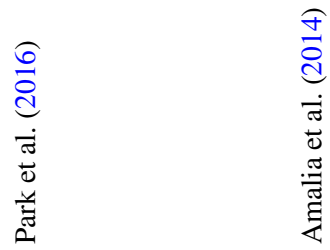

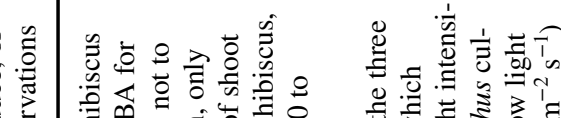

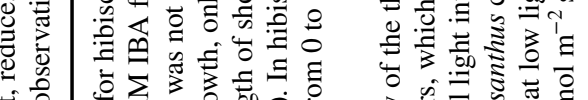

$\frac{\sqrt{\frac{9}{0}}}{\frac{0}{0}}$
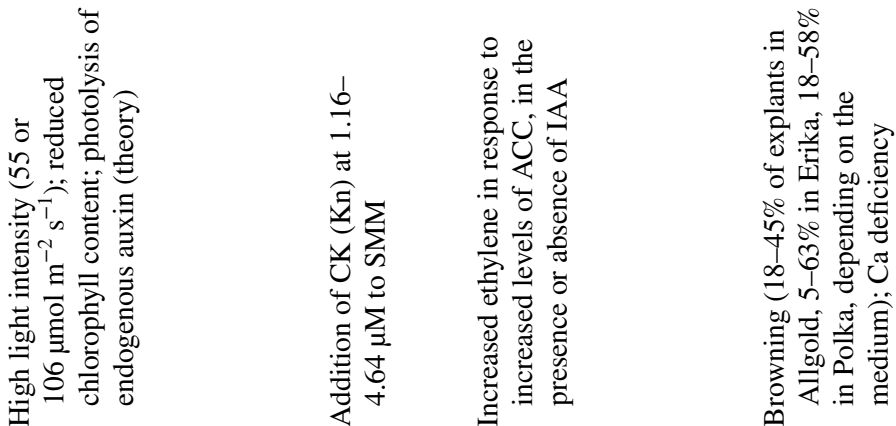

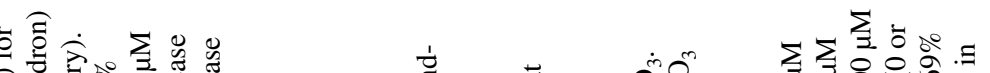

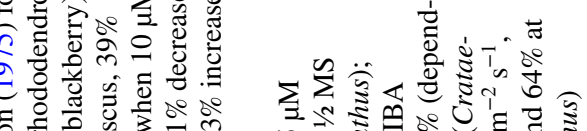

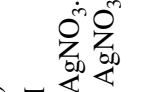

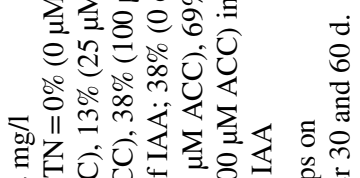

$\sum_{m} \sum_{i}$

in
$\infty$

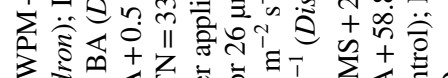

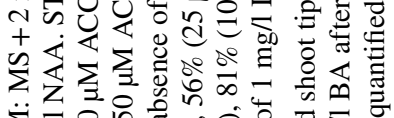

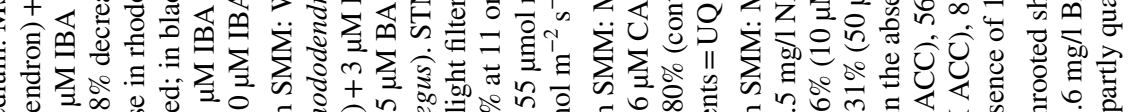

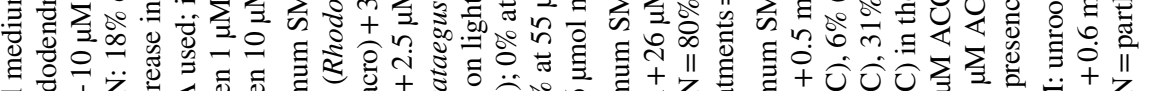

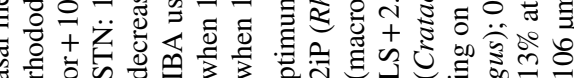
๑ึ

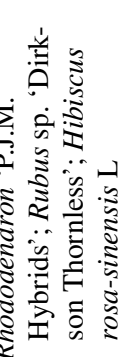
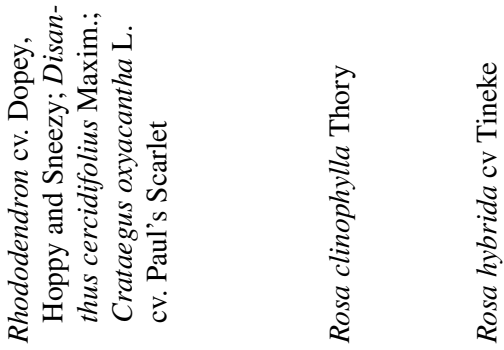

0
0
$\Xi$
0
0
0
0
0
0
0
0
0
0
0

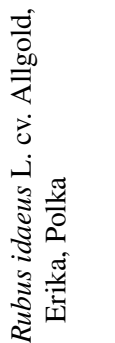




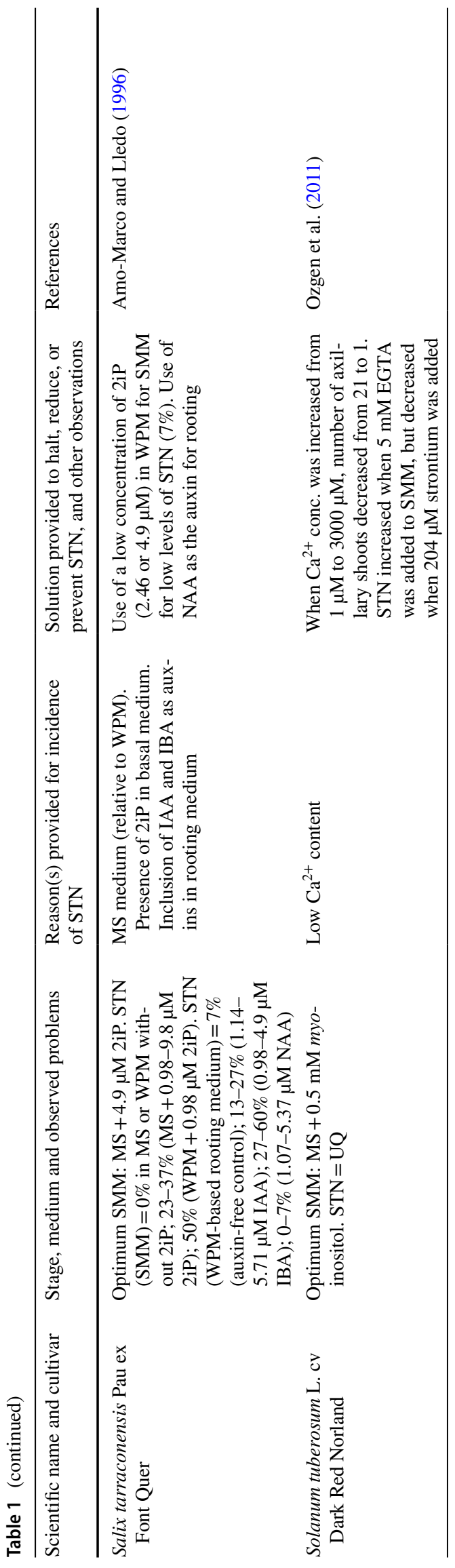

照 Springer 


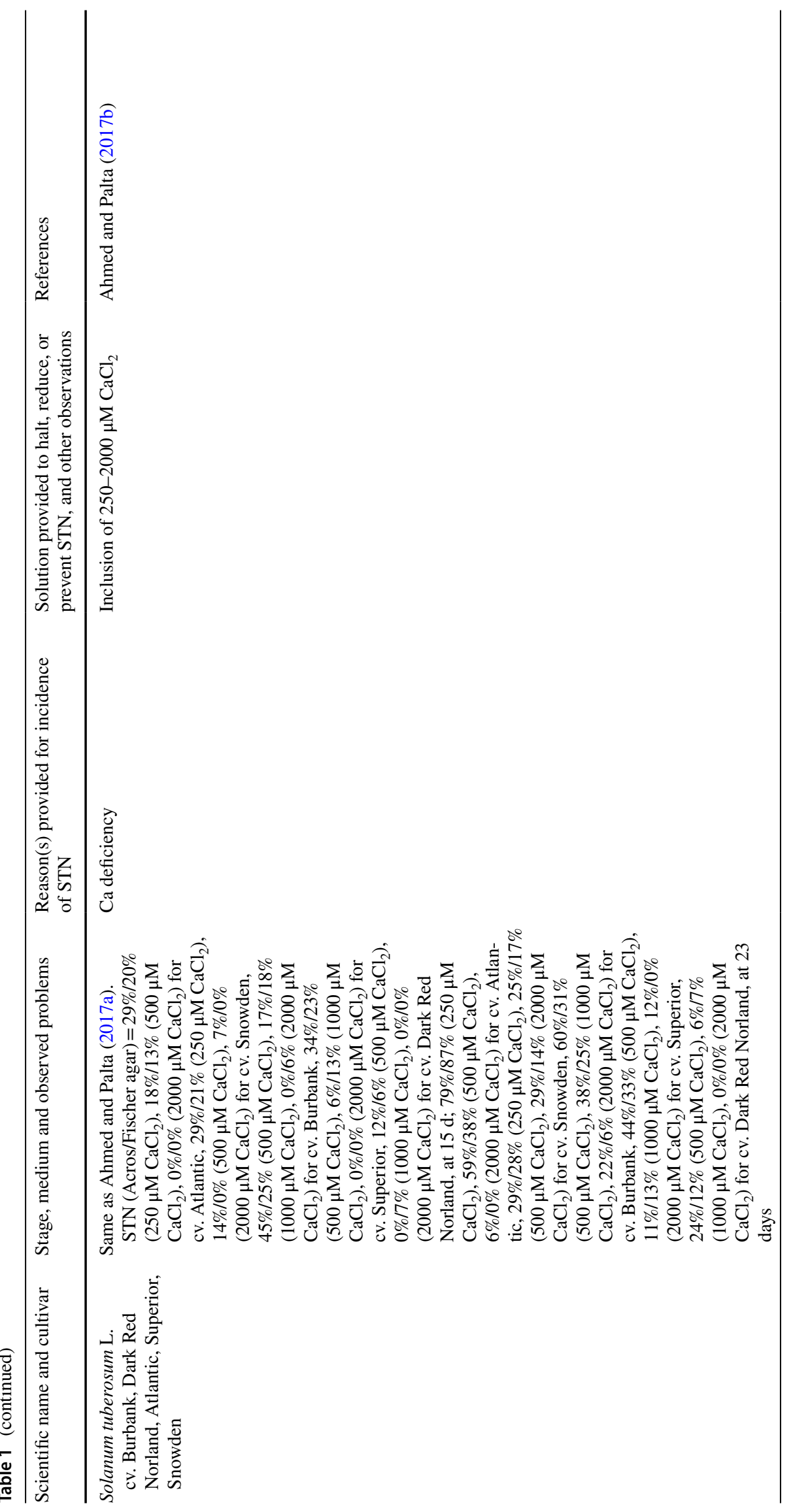




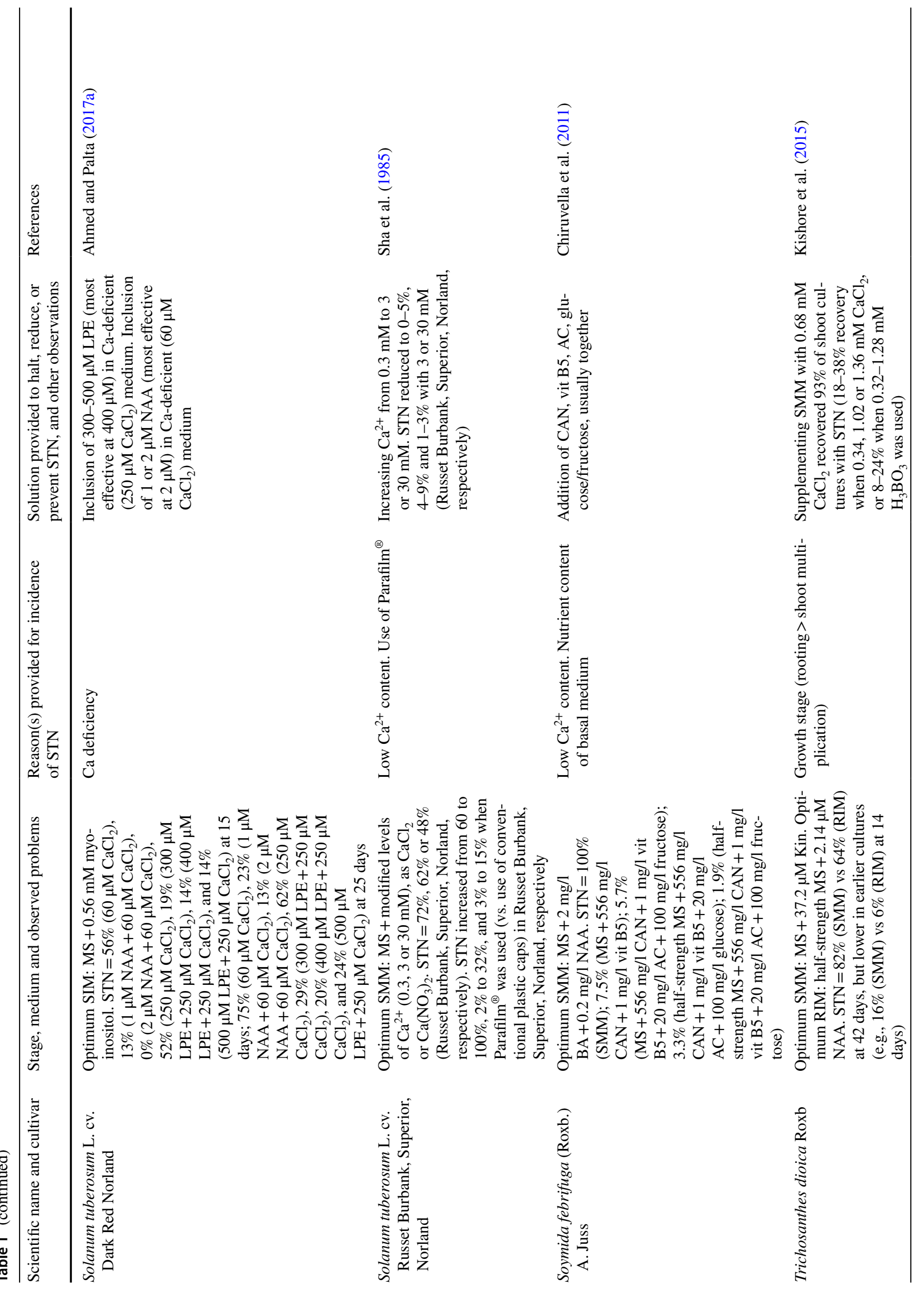




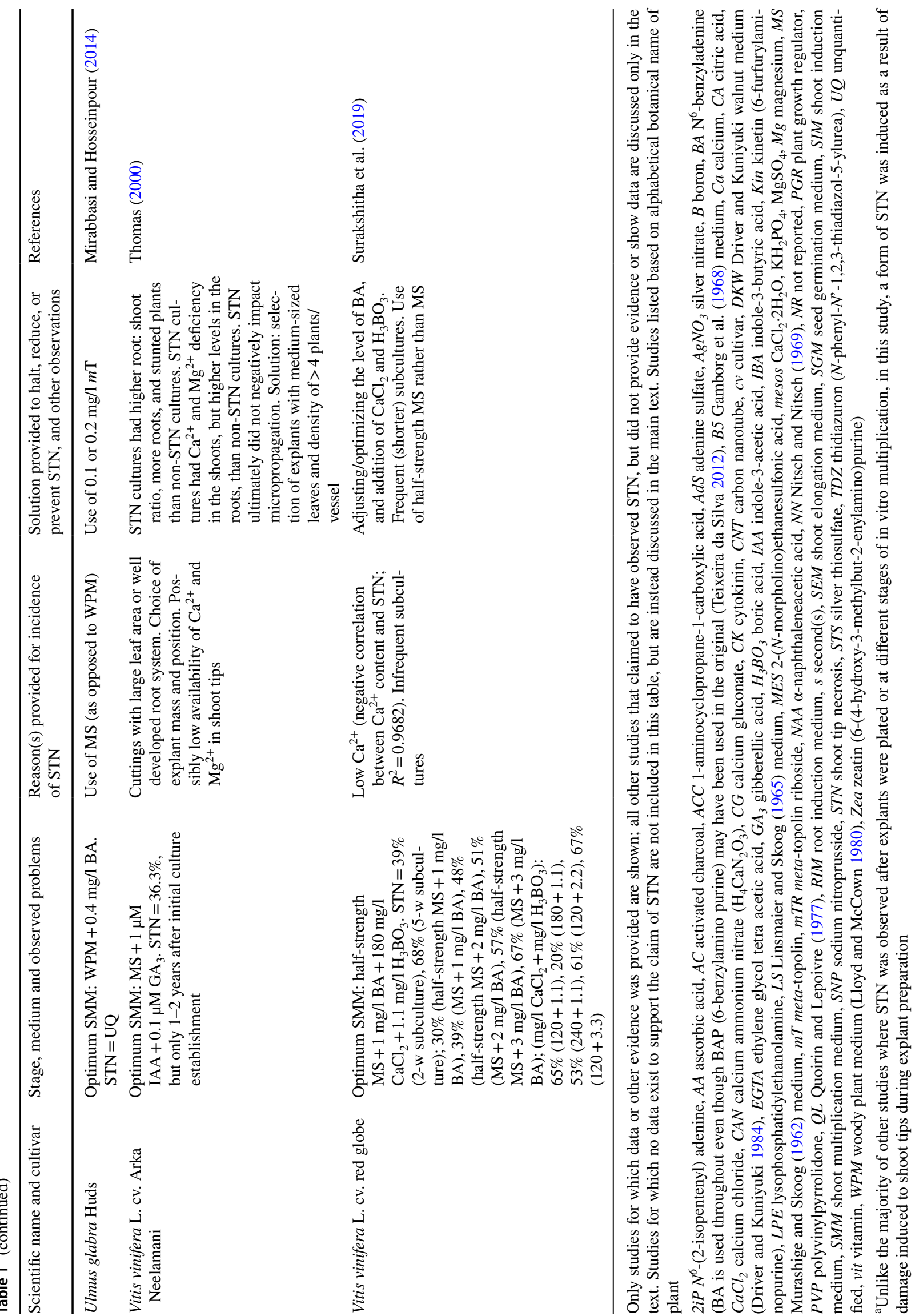


(WPM; Lloyd and McCown 1980). De Block (1990) also noted that the occurrence of STN might have been caused by a decrease in medium $\mathrm{pH}$, possibly as a result of ammonium $\left(\mathrm{NH}_{4}^{+}\right)$uptake by shoots. Relative to Murashige and Skoog (1962) (MS) medium, WPM has almost the same $\mathrm{Ca}^{2+}$ content $(\cong 3 \mathrm{mM}$ in WPM), about a quarter the concentration of $\mathrm{NH}_{4}^{+}(20.61$ vs $5.00 \mathrm{mM})$ and nitrate $\left(\mathrm{NO}_{3}^{-}\right)(39.41$ vs $9.71 \mathrm{mM})$, about two-thirds the content of $\mathrm{K}^{+}(20.05$ vs $12.61 \mathrm{mM}$ ), about a quarter of the $\mathrm{NH}_{4}^{+} / \mathrm{Ca}^{2+}$ ratio, but more than 1.5-times higher $\mathrm{Ca}^{2+} / \mathrm{K}^{+}$ratio (Suppl. Table 2). MS was employed in $68.6 \%$ of the studies listed in Table 1 while $21.4 \%$ used WPM. This suggests that the use of these basal media is not recommended, especially for trees and woody shrubs. This is curious if one considers that WPM was designed specifically for Ericaceous woody plants. The most popular theory for the cause of STN is related to nutrient deficiency and imbalance. Another is the impact and imbalance of PGRs. These possibilities are explored in greater detail next.

\section{Nutrient deficiencies}

\section{Calcium deficiency}

The most commonly ascribed reason for STN is Ca deficiency ( $32.8 \%$ of studies in Table 1). Table 1 indicates that one of the most popular methods to relieve STN has been to increase $\mathrm{Ca}^{2+}$ concentration in the culture media (35.9\% of studies in Table 1). In pistachio, Barghchi and Alderson (1985) suggested that STN was caused by Ca and boron (B) deficiency, but only on some shoots that had not rooted. Dolcet-Sanjuan and Claveria (1995) reduced STN by lowering the concentration of $\mathrm{Ca}^{2+}$ (as calcium chloride, $\mathrm{CaCl}_{2} \cdot 2 \mathrm{H}_{2} \mathrm{O}$ ) in medium to one-third of the level in MS, and by reducing the subculture period from 4-6 weeks to 3 weeks.

Kovalchuk et al. (2017a) used a CART (classification and regression tree analysis) decision tree to model the incidence of STN in wild apricot (Prunus armeniaca L.) shoot cultures based on previous response surface methodology (RSM). They noted that no STN developed in wild apricot shoots when $\mathrm{CaCl}_{2} \cdot 2 \mathrm{H}_{2} \mathrm{O}$ was $<2.94 \mathrm{mM}$, which is the precise concentration of $\mathrm{CaCl}_{2} \cdot 2 \mathrm{H}_{2} \mathrm{O}$ in WPM medium (Suppl. Table 2). Furthermore, the Reed et al. (2013) study of pear (one of several connected studies), which was based on MS medium, noted an increase in STN with low mesos $\left(\mathrm{CaCl}_{2} \cdot 2 \mathrm{H}_{2} \mathrm{O}, \mathrm{MgSO}_{4} \cdot 7 \mathrm{H}_{2} \mathrm{O}, \mathrm{KH}_{2} \mathrm{PO}_{4}\right)$ but also the involvement of ammonium nitrate. Wang and van Staden (2001) doubled the concentration of $\mathrm{CaCl}_{2}$ in WPM to $6 \mathrm{mM}$ to reduce the incidence of STN in tree peony (Paeonia $\times$ suffruticosa Andrews) cultures. Machado et al. (2014) found that the incidence of STN was halved when the level of $\mathrm{CaCl}_{2} \cdot 2 \mathrm{H}_{2} \mathrm{O}$ was increased threefold from 440 to $1320 \mathrm{mg} / \mathrm{l}$ (from $3.96 \mathrm{mM}$ to $11.89 \mathrm{mM}$ ) in true lavender (Lavandula angustifolia Mill.) shoot multiplication medium. Christensen et al. (2008) completely eliminated STN in Chinese hibiscus (Hibiscus rosa-sinensis L.) shoot cultures after increasing $\mathrm{CaCl}_{2}$ concentration in $\mathrm{MS}$ from $2.99 \mathrm{mM}$ to $9 \mathrm{mM}$, independent of the $\mathrm{N}^{6}$-benzyladenine (BA) concentration used $(0.22$ or $2.2 \mu \mathrm{M})$. STN was observed in cultures of potato (Solanum tuberosum L.) 'Dark Red Norland' when insufficient $(68 \mu \mathrm{M}) \mathrm{CaCl}_{2}$ was provided, resulting in a loss of apical dominance and enhanced axillary branching, a response that did not occur when there was sufficient $(1360 \mu \mathrm{M})$ $\mathrm{Ca}^{2+}$ in medium (Busse et al. 2008). The level of $\mathrm{CaCl}_{2}$ was one of the factors that affected the level of STN in Indian lilac (Azadirachta indica A. Juss) cultures (Arora et al. 2010). In potato 'Dark Red Norland', Ozgen et al. (2011) ascribed the increase in STN, as a result of low $\mathrm{Ca}^{2+}$ levels in medium, to injury of the shoot tip and subsequent loss of apical dominance, thereby stimulating axillary shoot formation. In Indian redwood (Soymida febrifuga (Roxb.) A. Juss.) cultures, the simultaneous use of calcium nitrate and calcium pantothenate (vitamin B5) at intermediate concentrations could eliminate the incidence of STN (Chiruvella et al. 2011, 2014). Mubina et al. (2018) eliminated STN by doubling the MS-based levels of $\mathrm{CaCl}_{2}$ and $\mathrm{KNO}_{3}$ in chickpea (Cicer arietinum L.) shoot regeneration medium. Nutrient deficiencies or excesses sensu lato accounted for 9.4\% of the studies in Table 1. Thirugnanasampandan et al. (2009) found that an adjustment of $\mathrm{CaCl}_{2}$ and $\mathrm{MgSO}_{4}$ in sarasaparilla (Smilax zeylanica Vent.) shoot regeneration medium prevented STN. In lentil (Lens culinaris Medikus), increasing $\mathrm{Ca}^{2+}$ (up to $750 \mathrm{mg} / \mathrm{l}$, i.e., $6.75 \mathrm{mM}$ ) and BA concentration $(0.2-0.6 \mathrm{mg} / \mathrm{l}$, i.e., $0.89-2.66 \mu \mathrm{M})$ in MS and B5 (Gamborg et al. 1968) basal media decreased the incidence of STN (Ye et al. 2002). That decision that was based on earlier research by Parh et al. (1998). Wetzstein et al. (1989) noted STN during the acclimatization stage of pecan nut (Carya illinoensis (Wangenh.) K. Koch) and not in vitro, reducing its incidence by applying a foliar spray of $0.4 \%$ calcium nitrate.

Another way to increase $\mathrm{Ca}$ concentration in plant culture medium is using calcium gluconate $(6.3 \%$ of studies in Table 1), usually from the start of shoot induction or multiplication stages (McCown and Sellmer 1987). The application of Ca-gluconate during in vitro culture of hybrid aspen (Populus alba $\times$ Populus tremula) and poplar (Populus trichocarpa $\times$ P. deltoides) eliminated STN in $50 \%$ of the shoots (De Block 1990). However, if $3 \mathrm{mM} \mathrm{Ca-gluconate}$ was combined with $0.5 \mathrm{mg} / \mathrm{l}(2.5 \mu \mathrm{M}) 2$-( $N$-morpholino $)$ ethanesulfonic acid ( $\mathrm{pH}$ 5.8), a buffer, then STN was totally eliminated. This may be because Ca-gluconate uptake into cells has a different pathway, via the glucose uptake system, and this form of $\mathrm{Ca}^{2+}$ does not involve the release of toxic chloride if $\mathrm{CaCl}_{2}$ is used, allowing medium $\mathrm{pH}$ to be 

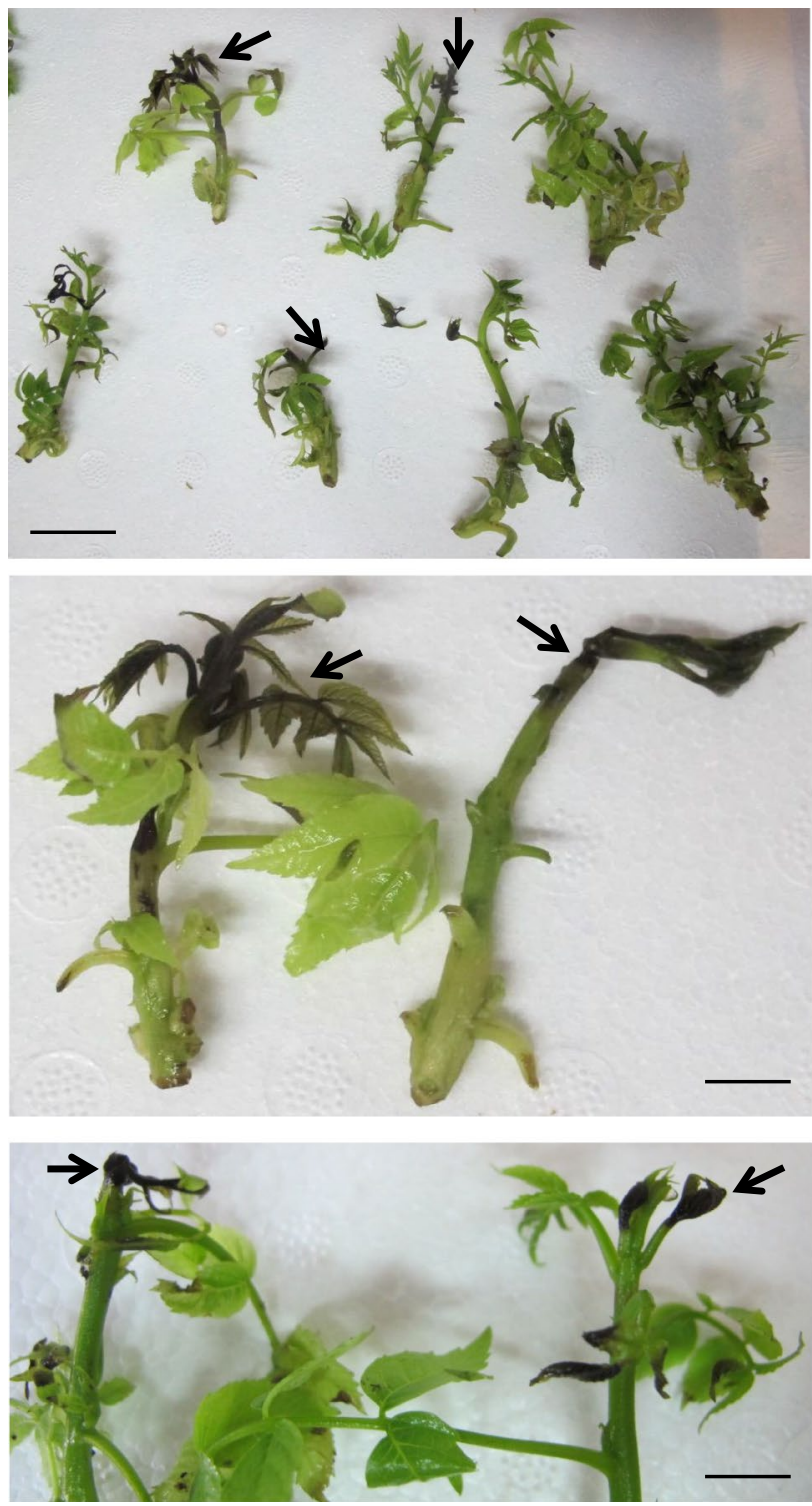

Fig. 2 Incidence of shoot tip necrosis (STN) in in vitro cultures of walnut (Juglans regia L.) Paradox rootstock during micropropagation in Driver and Kuniyuki walnut medium (DKW; Driver and Kuniyuki, 1984) (unpublished results). (1) if 3-week-old shoots were used, the incidence of STN was high (20-30\%), most likely because tissue is soft (non-lignified), but the use of 4-week-old shoots, which are more lignified, have a lower incidence of STN, even reduced to $0 \%$; (2) initial "Vlach" [a selection of Paradox ( $J$. hindsii x $J$. regia)] material is from a 110-year-old mother tree, located near Modesto (CA, USA) for which in vitro cultures were originally established by John Driver in 1985; (3) walnut tends to be somewhat recalcitrant to rooting, so occasionally high concentrations of IBA $(8-10 \mathrm{mg} / \mathrm{l})$ are added to rooting medium. If IBA is transported to the shoot tip, especially soft shoots that may take up excessive amounts of IBA, this may result in the death to the shoot tip, a condition we coin as "IBA burn", which is visually similar to STN. However, this does not take place if more mature shoots are used and this can be achieved by increasing the subculture interval from 3 to 4 weeks. Black arrows indicate STN. Scale bars indicate $3 \mathrm{~cm}$ (top), $2 \mathrm{~cm}$ (middle) and $2 \mathrm{~cm}$ (bottom) stabilized and thus ion exchange and uptake to occur at an optimum pH range of 5.6-5.9 (Pasqua et al. 2002). However, the supply of additional $\mathrm{Ca}^{2+}$ via $\mathrm{CaCl}_{2}$ can also increase the concentration of chloride $\left(\mathrm{Cl}^{-}\right)$ions, similar to the use of $\mathrm{NaCl}$, and this may be toxic to plant tissues (McCown and Sellmer 1987). In wild apricot, Pérez-Tornero and Burgos (2000) found that the addition of calcium nitrate or Cagluconate decreased the incidence of STN but also lowered rooting ability.

Shoot growth rate may be balanced by $\mathrm{Ca}^{2+}$ supply to shoots to avoid STN. This balance might depend on species and cultivars, the concentration of other nutrients in the medium that might modify $\mathrm{Ca}$ uptake, as well as the tissue or plant's developmental stage. The form of $\mathrm{Ca}^{2+}$ may also affect STN since the same ion $\left(\mathrm{Ca}^{2+}\right)$ content (Suppl. Table 2) can be supplied by different additives (salts or organic forms), but with different uptake mechanisms (Thor 2019) and thus various effects on STN (Table 1). The organic form has a dual uptake mechanism: (1) after dissociation of the $\mathrm{Ca}^{2+}$ ion through the highly regulated $\mathrm{Ca}^{2+}$ uptake system which is strongly affected by the culture conditions $(\mathrm{pH}$, relative concentration of other cations and anions, etc.); (2) without dissociation, the organic form of calcium is taken up directly into the cytoplasm via the uptake system but the organic part is under completely different regulation (White and Broadly 2003).

\section{Boron deficiency}

Unlike Ca deficiency, where the effect of STN occurs on younger leaves in the growing meristem and develops basipetally, STN caused by B deficiency $(6.3 \%$ of studies in Table 1) affects older leaves and spread upwards, or acropetally, as was reported in pistachio (Abousalim and Mantell 1994). Martinelli (1988) indicated the same problem in zebrawood (Pistacia integerrima J.L. Stewart ex Brandis) and Mt. Atlas mastic tree (Pistachia atlantica Desf.). Similarly, Parfitt and Almehdi (1994) found STN in hybrid pistachio UCB-1 ( $P$. atlantica $\times P$. integerrima), independent of the basal medium used, suggesting that the condition was not based on nutrients. Abousalim and Mantell (1994) confirmed these findings, noticing STN in P. vera cv. Mateur shoot cultures, but partially resolved this by adding calcium $\left(\mathrm{Ca}^{2+}\right)$ or boron $\left(\mathrm{BO}_{3}^{-}\right)$. Barghchi and Alderson (1996) used the same approach (see details in Table 1) but could also reduce STN using liquid medium. There is an interaction between $\mathrm{BO}_{3}^{-}$and $\mathrm{Ca}^{2+}$ uptake (Fox and Albrecht 1958): (1) a high $\mathrm{BO}_{3}^{-}$concentration can improve the uptake of $\mathrm{Ca}^{2+}$; (2) boron helps the movement of $\mathrm{Ca}^{2+}$ in plants. However, Abdulnour et al. (2000) described that high $\mathrm{BO}_{3}^{-}$concentrations could adversely affect $\mathrm{Ca}^{2+}$ uptake, even causing toxicity if $\mathrm{BO}_{3}^{-}$levels were as high as $0.4 \mathrm{mM}$, as in the case of devil's claw (Harpagophytum procumbens (Burch.) DC. ex 
Meisn.) (Bairu et al. 2009a). Boron deficiency often appears to occur in in vitro cultures of Pistachia species. However, the proper balance of nutrients should be assessed due to their interaction.

\section{Nitrogen deficiency: nitrogen form and quantity}

Grigoriadou et al. (2000) found that the occurrence of STN in pear was cultivar dependent and strongly related to the basal medium used. In their study, the application of Quoirin and Lepoivre medium (1977) resulted in the highest rate of STN (64\%) in the case of 'Highland', while they observed that most shoots were affected by STN on half-strength MS medium in 'Williams' (31\%). The former medium contains about a quarter the level of $\mathrm{NH}_{4}^{+}$, a quarter of the $\mathrm{NH}_{4}^{+} / \mathrm{NO}_{3}^{-}$ ratio, and only about $14 \%$ of the $\mathrm{NH}_{4}^{+} / \mathrm{Ca}^{2+}$ ratio compared to MS medium. However, the rate of STN was only $10 \%$ in 'Highland' and $14 \%$ in 'Williams' when shoots were cultured on WPM, in which the $\mathrm{NH}_{4}^{+} / \mathrm{NO}_{3}^{-}$ratio is the same as in MS medium but the total level of $\mathrm{N}$ and the $\mathrm{NH}_{4}^{+} / \mathrm{Ca}^{2+}$ ratio is only one-quarter of that in MS. In shoot cultures of wild apricot (Kovalchuk et al. 2017a), the use of RSM showed that some STN occurred in control shoot cultures in WPM. However, the influence of $\mathrm{NH}_{4}^{+}$and $\mathrm{NO}_{3}^{-}$was much stronger, i.e., when the concentration of these nutrients was low, STN was higher (Kovalchuk et al. 2017b). Ultimately, the recommended level of $\mathrm{NO}_{3}^{-}$was $>45 \mathrm{mM}$ (Kovalchuk et al. 2018). Excessive $\mathrm{NH}_{4}^{+}$and $\mathrm{NO}_{3}^{-}$in two pear rootstock cultures (12.3 and $13.2 \mathrm{mM}$ for OHF; 22 and $20.9 \mathrm{mM}$ for Pyrodwarf) resulted in STN (Jamshidi et al. 2016). In contrast, a shortage of $\mathrm{N}$ in dunns white gum (Eucalyptus dunnii Maiden) cultures resulted in STN, and the minimum level of $\mathrm{N}$ required was $27.7 \mathrm{~g} / \mathrm{kg}$ (Oberschelp and Gonçalves 2018). The total $\mathrm{N}$ content and/or the $\mathrm{NH}_{4}^{+} / \mathrm{NO}_{3}^{-}$ratio differ in several media commonly used for the micropropagation of various plant species (Suppl. Table 2; Phillips and Garda 2019). These can cause variation in the growth and developmental responses of in vitro shoots. From the above results, the occurrence of STN appears to depend mainly on the quantity and form of $\mathrm{N}$, the $\mathrm{NH}_{4}^{+} / \mathrm{Ca}^{2+}$ ratio, and the quantity of mesos elements [mainly $\mathrm{Ca}^{2+}$, magnesium $\left(\mathrm{Mg}^{2+}\right)$ and potassium $\left(\mathrm{K}^{+}\right)$] in medium (Reed et al. 2016; Kovalchuk et al. 2017a, b).

\section{Interaction of other ions on STN: the ion-confounding effect}

Unlike the above studies, which concluded that one of the main reasons for STN was Ca deficiency, some studies did not show any effect of $\mathrm{Ca}^{2+}$ on STN (4.7\% of studies in Table 1). When Piagnani et al. (1996) applied $\mathrm{CaCl}_{2}$ at 3, 9 or $18 \mathrm{mM}$, this did not reduce the incidence of STN in two sweet chestnut cultivars. In fact, $18 \mathrm{mM} \mathrm{CaCl}_{2}$ reduced rooting. When Grigoriadou et al. (2000) increased the level of $\mathrm{Ca}^{2+}$, this did not decrease the incidence of STN in pear. Thomas (2000) observed that the balance of $\mathrm{Ca}^{2+}$ and $\mathrm{Mg}^{2+}$ ions in roots and shoots was responsible for STN. Unlike the trend in most of these studies, Offord and Tyler (2009) found that the addition of $\mathrm{Ca}^{2+}$ to half-strength MS medium almost doubled STN in an endangered Australian shrub, pink pimelea (Pimelea spicata $\mathrm{R} . \mathrm{Br}$.).

Recently, the implementation of knowledge-based design of experiment (DOE) techniques has been widely used for understanding and improving the performance of complex in vitro systems (for example, Wada et al. 2015; Kovalchuk et al. 2017a). Niedz and Evens (2016) reviewed the greatest advantage of DOE in simultaneously minimizing the quantity of data while maximizing data quality based on considering only low order interactions in multi-factor studies ("hierarchical ordering") on the basis of "sparsity of effects" wherein just a few factors would drive the system efficiently (Box and Meyer 1986).

The use of DOE by Reed et al. (2013) enabled them to conduct a unique experiment to simultaneously study the effect of all macro- and microelements of MS medium on a wide range of physiological disorders in diverse pear germplasms. They divided mineral nutrients of MS medium into five independent groups with the advantage of reducing the required treatment numbers from $3125\left(5^{5}\right)$ to just 43 treatments. Noticeably, their findings asserted that STN is a genotype-dependent disorder that is affected by an imbalance of nutrients in culture media. Therefore, deficiencies in mesos $\left(\mathrm{CaCl}_{2} \cdot 2 \mathrm{H}_{2} \mathrm{O}, \mathrm{MgSO}_{4} \cdot 7 \mathrm{H}_{2} \mathrm{O}\right.$, and $\left.\mathrm{KH}_{2} \mathrm{PO}_{4}\right)$ or nitrogen (either $\mathrm{NH}_{4} \mathrm{NO}_{3}$ or $\mathrm{KNO}_{3}$ ) commonly contributed to STN. Wada et al. $(2013,2015)$ followed the same approach to improve the quality of many in vitro pear genotypes by readjusting nutrients in MS medium, such as increasing mesos $\left(\mathrm{CaCl}_{2}, \mathrm{MgSO}_{4}, \mathrm{KH}_{2} \mathrm{PO}_{4}\right)$ with increased nitrogen, to eliminate all physiological disorders. In their studies, STN was more evident with lower $\mathrm{Ca}^{2+}$ content than MS-based concentrations although lower concentrations of some mesos, including in the MS medium control, may have accounted for the disorders, although no general trend was observed. In addition to the level of $\mathrm{CaCl}_{2}$, Arora et al. (2010) reported that other nutrients, principally $\mathrm{Ca}\left(\mathrm{NO}_{3}\right)_{2}, \mathrm{Na}_{2} \mathrm{SO}_{4}$, and $\mathrm{K}_{2} \mathrm{SO}_{4}$ in basal MS medium, also affected the level of STN in Indian lilac (Azadirachta indica A. Juss.) cultures.

The next challenge of tissue culture studies are ion-confounding problems (Niedz and Evens 2006, 2007), wherein salts are subjected as factors in an experimental design and analysis rather than ions by themselves, whilst ions drive the system. For instance, many authors have frequently tried to alleviate STN in different species by increasing the amount of $\mathrm{MS}-\mathrm{CaCl}_{2}$ because this unique salt contains the $\mathrm{Ca}^{2+}$ ion. $\mathrm{CaCl}_{2}$ in MS medium releases $2.99 \mathrm{mM} \mathrm{Ca}^{2+}$ plus $6 \mathrm{mM} \mathrm{Cl}^{-}$into solution (Suppl. Table 2). Therefore, it is 
inconclusive to attribute the problem of STN exclusively to $\mathrm{Ca}^{2+}$ deficiency while the role of $\mathrm{Cl}^{-}$is completely overlooked. Numerous examples of this inconclusiveness can be found in the literature (Barghchi and Alderson 1996; Piagnani et al. 1996; Bairu et al. 2009a, 2009b; Ozgen et al. 2011; Machado et al. 2014; Poothong and Reed 2014; Surakshitha et al. 2019). Nevertheless, it has recently been proved that $\mathrm{Cl}^{-}(>4.67 \mathrm{mM})$ has a positive effect on reducing STN symptoms in pistachio (Nezami-Alanagh et al. 2019). To the best of our knowledge, the latter study was the first report of the beneficial effect of $\mathrm{Cl}^{-}$on controlling STN in plants.

Ca-gluconate has been reported as a way to alleviate STN in herbal medicinal plants (Srivastava and Joshi 2013), woody shrubs (Amalia et al. 2014), fruit trees (Abousalim and Mantell 1994; Pérez-Tornero and Burgos 2000), and other trees (De Block 1990; Pasqua et al. 2002). As far as we know, the only report to assess the individual role of the gluconate ${ }^{-}$ion $\left(\mathrm{C}_{6} \mathrm{H}_{11} \mathrm{O}_{7}^{-}\right)$in plant growth and development was Nezami-Alanagh et al. (2017). Using artificial intelligence models, a significant negative influence of gluconate ${ }^{-}$concentration (range $0.0-6.02 \mathrm{mM}$ ) on two growth parameters (shoot length and total fresh weight) during pistachio micropropagation was determined. Thus, we strongly advise to cautiously use gluconate in medium formulations for plant micropropagation. Moreover, we also encourage the use of any method (statistical, response surface methodology, chaid or artificial intelligence) that allows the simultaneous study, on one hand, of the effect of a single ion, and on the other hand, of interactions between several factors.

\section{Plant growth regulators affect STN}

Another popular theory to explain the cause of STN is the effect of the level and type of PGRs in the medium. STN has been linked to the level of PGRs in 23.4\% of the studies in Table 1. However, an increase in PGRs may alleviate some nutrient deficiencies (Preece 1995). This fortifies the notion that nutrient deficiency is the major cause of STN. STN in apple (Malus $\times$ domestica Borkh.) was attributed to low endogenous hormone content (Kataeva et al. 1991). According to Kataeva et al. (1991), in the absence of roots, where cytokinins (CKs) are mainly synthesized, endogenous CK concentrations in shoots decrease. This affects the synthesis of auxin in the shoot apical meristem, stimulating STN. In sweet chestnut and oak, the absence of CK (BA) in rooting medium, or the presence of a low concentration of BA, induced STN, although the application of BA to cut ends of shoots prior to rooting increased axillary shoot production (Vieitez et al. 1989). When Piagnani et al. (1996) added $5 \mu \mathrm{M}$ BA to sweet chestnut shoot tips, STN was eliminated, but a mixture of $5 \mu \mathrm{M}$ BA and $3 \mathrm{mM} \mathrm{CaCl}_{2}$ delayed STN. A
$\mathrm{CK} \times \mathrm{Ca}^{2+} \times \mathrm{BO}_{3}^{-}$interaction on STN was observed in grape (Vitis vinifera $\mathrm{L}$.) cv. Red Globe where supplementary $\mathrm{CaCl}_{2}$ and $\mathrm{H}_{3} \mathrm{BO}_{3}$ were needed to suppress STN, even after the level of BA had been optimized (Surakshitha et al. 2019). Thomas (2000) observed that CK concentration had no signficant effect on STN. Surakshitha et al. (2019) did not observe this effect in grape; instead, the level of STN depended on BA concentration. When BA concentration was increased from $8.9 \mu \mathrm{M}(0 \% \mathrm{STN})$ to $17.8 \mu \mathrm{M}$, cane apple (Arbutus unedo L.) cultures displayed $8.7 \%$ STN (Gomes et al. 2010). Pérez et al. (1985) reduced STN in filbert (Corylus avellana L.) by adding indole-3-butyric acid (IBA) to medium at a low concentration $(10$ or $25 \mu \mathrm{M})$, or by reducing the period of exposure to IBA. In apricot, dipping shoot tips in a solution of BA (1.78-3.11 $\mu \mathrm{M}$, depending on the cultivar) prior to culture in rooting medium alleviated STN while kinetin had no effect (Pérez-Tornero and Burgos 2000). The mere presence of $2.5 \mu \mathrm{M}$ BA in MS medium induced STN in moringa (Moringa oleifera Lam.) (Hassanein et al. 2018). In pistachio micropropagation, STN was significantly reduced when BA was added at high concentrations $(5.77<\mathrm{BA}<6.66 \mu \mathrm{M})$ to basal media (Nezami-Alanagh et al. 2019).

In contrast, in blackberry (Rubus sp. 'Dirkson Thornless'), rhododendron (Rhododendron 'P.J.M. Hybrids') and Chinese hibiscus, when Compton and Preece (1988) increased BA concentration to $10 \mu \mathrm{M}$, STN increased (details in Table 1). Norton and Norton (1985) also noticed STN in Gaultheria sp. and Rhododendron sp. (Ericaceae) when any concentration of BA was used, although 17 other Ericaceae species did not show STN. As mentioned above, Podwyszyńska and Goszczyńska (1998) found that when indole-3-acetic acid (IAA) was present in medium, the incidence of STN increased in rooting cultures of dwarf rose (Rosa gymnocarpa Nutt. 'Starina'). Lin et al. (2011) also observed STN in Korean pasque flower (Pulsatilla koreana) shoots on MS-based rooting medium containing BA and IAA. Serres et al. (1990) observed STN in American chestnut (Castanea dentata [Marsh.] Borkh.) in rooting medium containing IBA, and only the top node was affected, allowing lower axillary shoots to form shoots and thus not influencing explant survival. Bairu et al. (2009a) found that the inclusion of BA increased STN in devil's claw, even more so when an auxin (IAA) was also added. However, the inclusion of meta-topolin $(m \mathrm{~T})$ or meta-topolin riboside ( $m \mathrm{TR}$; more background in Aremu et al. (2012)) could reducebut not eliminate- the incidence of STN. Kinetin stimulated STN in Rosa clinophylla Thory cultures (Misra and Chakrabarty 2009). In buchu (Coleonema pulchellum I.Williams) shoot-inducing cultures, STN only occurred when thidiazuron (TDZ) was applied at $13.6 \mu \mathrm{M}$ in MS basal medium, or in response to $300 \mu \mathrm{M}$ casein hydrolysate or mebendazole, $40 \mu \mathrm{M}$ glutamine, or $40 \mu \mathrm{M}$ glutamine in combination with 4.5 $\mu \mathrm{M}$ TDZ (Baskaran et al. 2014). STN was also observed 
in grape ivy (Cissus rhombifolia Vahl, syn. Cissus alata Jacq.) shoot cultures grown in the presence of $4.5 \mu \mathrm{M} \mathrm{TDZ}$, but not in response to $4.4 \mu \mathrm{M}$ BA (Dewir et al. 2018). The use of $2 \mu \mathrm{M}$ TDZ, or even the lack of TDZ, induced STN in $100 \%$ of white saxaul (Haloxylon persicum (Bunge ex Boiss and Buhse)) shoot cultures. The latter was also associated with stem fasciation, a common response to high concentrations of TDZ (Dewir et al. 2018). Intermediate concentrations $(0.5$ or $1 \mu \mathrm{M})$ of TDZ reduced the incidence of STN by $10-14 \%$ (Kurup et al. 2018). The incidence of STN was reduced when 0.1 or $0.2 \mathrm{mg} / \mathrm{l}(0.8 \mu \mathrm{M}) m \mathrm{~T}$ was added to the shoot multiplication medium of Scots elm (Ulmus glabra Huds.) shoots (Mirabbasi and Hosseinpour 2014). When Marín et al. (2016) replaced BA with $5 \mu \mathrm{M} m \mathrm{~T}$ in pistachio shoot culture medium, STN was reduced to $20 \%$ of cultures.

The application of $15 \mathrm{mg} / \mathrm{l}(40.7 \mu \mathrm{M})$ adenine sulfate prevented STN in nannaari (Hemidesmus indicus (L.) R.Br.) (Nagahatenna and Peiris 2007). When Naaz et al. (2014) added $100 \mathrm{mg} / \mathrm{l}(271.3 \mu \mathrm{M})$ adenine sulfate to BAsupplemented MS medium (WPM resulted in higher levels of STN), STN was reduced to $10 \%$ in jambolan (Syzygium cumini (L.) Skeels.) shoot cultures.

Several other studies assessed the ability of PGRs to reduce STN. Podwyszyńska and Goszczyńska (1998) significantly reduced the incidence of STN in dwarf rose rooting medium containing IAA by adding $2.5-10 \mathrm{mg} / \mathrm{l}$ $(14.7-58.8 \mu \mathrm{M})$ silver nitrate $\left(\mathrm{AgNO}_{3}\right)$, and by increasing the level of MS-based $\mathrm{Ca}^{2+} 1.5$-fold (increasing the level of MS-based $\mathrm{Mg}^{2+}$ twofold was optional). $\mathrm{AgNO}_{3}$ is an effective ethylene inhibitor (Purnhauser et al. 1987). Vieitez et al. (2009) reduced the incidence of STN in northern red oak (Quercus rubra L.) cultures by supplementing medium with $3 \mathrm{mg} / \mathrm{l}(17.6 \mu \mathrm{M}) \mathrm{AgNO}_{3}$. Martínez et al. (2017) found that $\mathrm{AgNO}_{3}$ at $20 \mu \mathrm{M}$ reduced the incidence of STN in evergreen oak (Quercus ilex L.) cultures. Park et al. (2016) found that the production of ethylene in rose (Rosa hybrida cv. Tineke) shoot multiplication medium increased the level of STN. They proved this by applying different levels of an ethylene promoter, 1-aminocyclopropane-1-carboxylic acid (ACC), to medium. Ahmed and Palta (2017a) reduced the incidence of STN in $\mathrm{Ca}^{2+}$-deficient (6.7 or $27.75 \mathrm{mg} / \mathrm{l}(60.3-250 \mu \mathrm{M})$ $\mathrm{CaCl}_{2}$ ) potato shoot induction medium by adding 1 or $2 \mu \mathrm{M}$ NAA, or 300-500 $\mu \mathrm{M}$ lysophosphatidylethanolamine (a phospholipid). Curiously, Ahmed and Palta (2017b) found that agars with different levels of $\mathrm{Ca}^{2+}$ significantly affected the level of STN: Acros agar was $\mathrm{Ca}^{2+}$ deficient $(22.92 \mathrm{mg} / \mathrm{l}$ $(0.5718 \mathrm{mM}))$ while Fischer Scientific agar was slightly $\mathrm{Ca}^{2+}$ deficient $(84.36 \mathrm{mg} / \mathrm{l}(2.1 \mathrm{mM}))$ relative to the control (MS Ca level $=3000 \mu \mathrm{M}$ or $120.23 \mathrm{mg} / \mathrm{l}$ ). However, supplementation with $27.75-221.96 \mathrm{mg} / \mathrm{l}(0.25-1.99 \mathrm{mM})$ $\mathrm{CaCl}_{2}$ reduced or eliminated STN in five potato cultivars (see details in Table 1). If auxin is used in excess, especially in juvenile pistachio cultures at the rooting stage, STN may develop (Fig. 2).

The ability of endogenous and exogenously added PGRs to alter the level of STN in response to PGR type and concentration, especially during the rooting phase, suggests their important role in STN. To limit or prevent STN, an adequate level of BA and TDZ should be applied, while the application of $m \mathrm{~T}$ and/or its derivatives may be beneficial. Broadly, altering the type or level of exogenously applied PGRs in plant in vitro cultures might not impact STN exclusively, but might also impact many mechanisms, while different genera or species might respond differently (Cardoso et al. 2018). Auxins should not be used at excessive concentrations while ethylene production should be inhibited as much as possible. Excessive ethylene production in plant in vitro cultures can be avoided by applying auxins at a suitable concentration, by increasing aeration of culture vessels (Kumar et al. 1998), using aerated containers, or it can be inhibited by applying ethylene inhibitors such as $\mathrm{AgNO}_{3}$ (Teixeira da Silva 2013).

\section{Other factors and interactions impacting the incidence of STN}

\section{Timing of measurements and subculture length}

Grigoriadou et al. (2000) noted that the level of STN was much higher at 4 weeks than at 2 weeks, suggesting that sampling time influenced the quantitative outcome. This issue was not raised in most other studies on STN but is an important issue to consider when dealing with plant tissue cultures (Teixeira da Silva and Dobránszki 2013). Srivastava and Joshi (2013) found that STN was 62\% after 2 weeks, but $90 \%$ after 4 weeks in rose moss (Portulaca grandiflora Hook.) cultures. The same time-dependent incidence of STN was observed in tissue cultures of five pear cultivars (Thakur and Kanwar 2011). The time-sensitive outcome of STN was also observed by Kishore et al. (2015) in pointed gourd (Trichosanthes dioica Roxb. var. Swarna Alaukik). They observed higher STN (83\%) during shoot multiplication at 42 days than at 14 (16\%), 21 (44\%), 28 (61\%), and 35 (72\%) days on MS medium containing 3\% sucrose, $0.8 \%$ agar, $0.02 \%$ carbendazim and $37.17 \mu \mathrm{M}$ kinetin. Ahmed and Palta (2017a) observed 56\% STN in $\mathrm{Ca}^{2+}$-deficient $\left(60 \mu \mathrm{M} \mathrm{CaCl}_{2}\right.$; $52 \%$ STN with $250 \mu \mathrm{M} \mathrm{CaCl}_{2}$ ) shoot induction medium of potato cv. Dark Red Norland when sampled at 15 days, but $75 \%$ STN after 25 days (62\% STN with $250 \mu \mathrm{M} \mathrm{CaCl}_{2}$ ). In other words, reported STN levels were higher in older cultures. Similarly, Ahmed and Palta (2017b) found higher levels of STN in the majority of five potato cultivars (i.e., a genotype-specific response) when two $\mathrm{Ca}^{2+}$-deficient agar brands were used in shoot induction medium and sampled at 
23 days relative to 15 days. Thakur and Kanwar (2011) also observed STN during in vitro rooting on semisolid and liquid medium in five pear cultivars: $6 \%, 28 \%, 39 \%, 49 \%$, and $64 \%$ of cultures displayed STN at 14, 21, 28, 35, and 42 days (details in Table 1). Sudha et al. (1998) attributed a long culture period, in excess of 8 months, to the incidence of STN in arka (Holostemma annulare (Roxb.) K. Schum.). Amin and Jaiswal (1988) also attributed STN to excessive subculture length in guava (Psidium guajava $\mathrm{L}$.) for $\mathrm{cv}$. Chittidar during shoot tip (derived from mature plants) culture on MS medium with 4.4 $\mu \mathrm{M}$ BA. Papadatou et al. (1990), however, did not observe any STN when seedling-derived shoot tips of the same guava cultivar was used on Rugini olive medium (Rugini 1984) with $8.8 \mu$ M BA. Delaying the subculture period longer than 2 weeks induced STN in rose and miniature Chinese rose (Rosa chinensis minima (Sims) Voss.) (Hsia and Korban 1996). $\mathrm{Ca}^{2+}$ concentration that exceeded $6 \mathrm{mM}$ negatively impacted Pistacia vera shoot growth and increased shoot chlorosis, but a reduction of the subculture period from 4-5 weeks to 3 weeks reduced the incidence of STN (Dolcet-Sanjuan and Claveria 1995). Tilkat et al. (2008) also found 3 weeks to be suitable for reducing STN in pistachio cultures. Alderson et al. (1987) suggested that increasing the frequency of subcultures, thus reducing the subculture period, could reduce the incidence of STN in dwarf Russian almond (Prunus tenella Batsch). A longer subculture length was also associated with hyperhydricity, which is frequently caused by the accumulation of ethylene in cultures (Park et al. 2004).

These results are not surprising. One cause of STN is the deficiency of nutrients, so the chance of nutrient deficiencies within a subculture increases over time as nutrients become depleted (Ramage and Williams 2002). The timing of sampling can influence the reported outcome of STN, although the likelihood of STN is higher in older cultures and may be related to changes in the nutrient content of tissue culture medium over time.

\section{Genotype-specific responses}

Mythili and Thomas (1999) successfully micropropagated two female cultivars (Swarna Alaukik and Swarna Rekha) and one male line of pointed gourd on MS medium but noted a decline in transferable nodes in Swarna Alaukik due to leaf chlorosis if subculture was delayed by 8 weeks. In contrast, no symptoms of STN were observed in pointed gourd accession IIVRPG-102 (Kumar et al. 2016), suggesting that STN could be a genotype-specific response or due to the presence of carbendazim, as was also reported by Kishore et al. (2015). Thakur and Kanwar (2011) observed STN between the 6th and 8th week at the shoot regeneration stage in three pear rootstocks (P. pyrifolia [Burm F.] Nakai, $P$. pashia Buch. Ham. and P. serotina Rehd.), and two scion cultivars 'Patharnakh' (P. pyrifolia [Burm F.] Nakai) and 'Punjab Beauty' ( $P$. pyrifolia $x$ P. communis), but the level of STN was dependent on genotype. Thakur and Kanwar (2011) found a genotype dependence in response to $\mathrm{Ca}$ and B supplementation. When $3 \mu \mathrm{M} \mathrm{Ca}^{2+}$ (up from $1.5 \mu \mathrm{M}$ ) and $200 \mu \mathrm{M} \mathrm{BO}_{3}^{-}$were used, this completely alleviated the incidence of STN in the wild cultivar (from $9.12 \%$ to $2.60 \%$ ) but had no significant effect nor did it prevent STN in the remaining four cultivars. In London plane tree (Platanus acerifolia (Ait.) Willd), Alegre et al. (2015) found a clear influence of genotype on the incidence of STN during shoot multiplication, with a wide range $(\sim 20-69 \%)$ of affected cultures that was genotype dependent. Thus, the susceptibility of a plant to develop STN might be both species and cultivar dependent.

\section{Choice of basal medium}

Bosela and Michler (2008) also noticed that the choice of basal medium affected the level of STN in Eastern black walnut (Juglans nigra L.). However, this was also dependent on the in vitro developmental stage and the CK used, with higher levels of STN observed in the presence of Driver and Kuniyuki walnut medium (DKW; Driver and Kuniyuki 1984) and zeatin. Similarly, in unpublished results, STN was observed in vitro cultures of walnut Paradox rootstock during micropropagation in DKW medium (Fig. 2). Shoots were first multiplied on DKW basal medium supplemented with $1 \mathrm{mg} / \mathrm{l}(4.4 \mu \mathrm{M}) \mathrm{BA}, 0.1 \mathrm{mg} / \mathrm{l}(0.49 \mu \mathrm{M}) \mathrm{IBA}$ and $30 \mathrm{~g} / \mathrm{l}$ sucrose and subcultured every 3 weeks. Three-weekold shoots, in preparation for rooting, were first placed in the dark for 5 days at $24{ }^{\circ} \mathrm{C}$. STN was observed in rooting medium consisting of DKW free of cytokinins (BA), but including $10 \mathrm{mg} / \mathrm{l}(44 \mu \mathrm{M})$ IBA and $50 \mathrm{mg} / \mathrm{l}(146 \mu \mathrm{M})$ sucrose. After 5 days in rooting medium, auxin-induced shoots were placed in a greenhouse and exposed to high relative humidity ( $>95 \%$ ). These induced shoots rooted and acclimatized concurrently ex vitro.

Curiously, García et al. (2011) observed quite the opposite in pistachio where DKW medium resulted in lower levels of STN than in MS or WPM media. They attributed STN to the three times higher levels of $\mathrm{Ca}^{2+}$ in DKW (relative to MS and WPM). Moreover, some authors previously recommended the inclusion of calcium gluconate to prevent STN (Abousalim and Mantell 1994). However, Nezami-Alanagh et al. (2017) fund that gluconate ${ }^{-}$had an adverse effect on in vitro pistachio plant growth. In high-bush blueberry (Vaccinium corymbosum L.), the use of MS medium induced STN, especially when $0.5 \mathrm{mg} / \mathrm{l}$ zeatin was used with higher concentrations $(>1 \mathrm{mg} / \mathrm{l})$ of IBA, but when this was replaced by Anderson's rhododendron medium (Anderson 1984), STN was eliminated (Ružić et al. 2012). Anderson's 
rhododendron medium, relative to MS medium, contains about one-quarter the concentration of $\mathrm{K}^{+}, \mathrm{NH}_{4}^{+}$and $\mathrm{NO}_{3}^{-}$ (Suppl. Table 2). Martin et al. (2007) tested several factors, including PGRs, carbohydrate sources, and $\mathrm{AgNO}_{3}$, in the media of subcultured necrotic shoots to try and improve the incidence of STN in in vitro banana (Musa spp.) cultures. Normal shoots were recovered only with the addition of $50-100 \mathrm{mg} / 1(0.45-0.9 \mathrm{mM})$ of $\mathrm{CaCl}_{2}$. When full-strength MS medium was used, STN was observed in Zeyheria montana Mart. cultures, but not when half- or quarter-strength MS was used (Cardoso and Teixeira da Silva 2013). Similarly, full-strength MS medium induced STN in Barbados nut (Jatropha curcas L.) cultures, but not half-strength MS (Daud et al. 2013), an outcome that Dangi et al. (2014) also observed for bahera (Terminalia bellerica (Gaertn.) Roxb.). Using basal CK medium that had diluted levels of MS microand macronutrients (Cellárová et al. 1992), Moura (1998) found $15 \%$ and $23 \%$ STN in shoot initiation and elongation stages, respectively, of leafy St. John's wort (Hypericum foliosum Aiton). The use of WPM induced more STN than MS in the multiplication of wych elm (Ulmus glabra Huds.) shoots (Mirabbasi and Hosseinpour 2014). Consequently, the choice of appropriate basal medium can be a solution in itself. Further, altering the level of certain ions, especially $\mathrm{Ca}^{2+}$, can also help to reduce STN. However, changing a single medium constituent might affect the uptake or utilization of other nutrients, while agar source and type may affect micronutrients, as discussed elsewhere in this review. Thus, this solution should be viewed cautiously. Moreover, several species responded well to reduced MS salts.

\section{Antioxidants}

Amalia et al. (2014) also noticed some (unquantified) reduction in STN of raspberry (Rubus idaeus L.) shoots when 50 or $100 \mathrm{mg} / \mathrm{l}(0.284-0.568 \mathrm{mM})$ of ascorbic acid was used, but not as effectively as the use of $1 \mathrm{~g} / \mathrm{l} \mathrm{Ca}$-gluconate. The reduction in STN was also genotype dependent. Misra et al. (2010) were also able to reduce STN in Barbados nut cultures by adding antioxidants, either $25 \mathrm{mg} / \mathrm{l}(81.3 \mu \mathrm{M})$ of reduced glutathione or $10 \mathrm{mg} / \mathrm{l}(56.7 \mu \mathrm{M})$ of ascorbic acid. Jaiswal et al. (2013) observed STN in Indian kino tree (Pterocarpus marsupium Roxb.) cultures. They eliminated STN by adding $568 \mu \mathrm{M}$ ascorbic acid, $260 \mu \mathrm{M}$ citric acid, $605 \mu \mathrm{M}$ ammonium sulfate, and $217 \mu \mathrm{M}$ adenine sulfate to MS basal medium. By adding 1\% activated charcoal to root proliferation medium, Sánchez et al. (1997) reduced the incidence of STN from 89 to $30 \%$ in sweet chestnut clone 90,025 and from 38 to $13 \%$ in clone Pr5. The addition of antioxidants to basal medium during shoot multiplication might be an effective way to reduce or prevent STN.

\section{Humidity, aeration, and hyperhydricity: is there a link to STN?}

High humidity and weak ventilation in culture vessels can cause abnormalities, including hyperhydricity (Lai et al. 2005), or STN (Fig. 3a). These abnormalities may in turn be caused by increased ethylene production (Isah 2015). A decrease in humidity within culture vessels can be achieved by improving the ventilation of vessels, or by increasing the agar concentration in basal medium. The former can encourage gas exchange, thereby decreasing ethylene concentration within the vessel (reviewed in Isah 2015). In their summary, Bairu et al. (2009b) concluded that better aeration decreased STN. Barghchi and Alderson (1983, 1985, 1996), in addition to stating that STN was caused by Ca deficiency, also proposed that STN was linked to high humidity in a culture vessel. They found that high humidity reduced plantlet transpiration rate, causing a "low mobility of calcium ions in the xylem", i.e., reduced nutrient flow to meristematic regions in growing shoot tips. Several authors found that high relative humidity and low transpiration caused by closed culture vessels decreased $\mathrm{Ca}^{2+}$ flow during transpiration, causing $\mathrm{Ca}$ deficiency (Sha et al. 1985; Singha et al. 1990; Abousalim and Mantell 1994) (Fig. 3a).

$\mathrm{Ca}^{2+}$ transport is inhibited by apoplast flooding in which apoplastic air spaces are blocked as a result of water clogging (van den Dries et al. 2013). Bhalla and Mulwa (2003) noted that when $\mathrm{Ca}^{2+}$ in medium exceeded $6 \mathrm{mM}$ in macadamia nuts (Macadamia F. Muell.), STN symptoms increased. They found that this was as a result of poor culture vessel aeration and high relative humidity and was not linked to $\mathrm{Ca}^{2+}$ level in the medium. McCown and Sellmer (1987) suggested that when culture vessels that increase gas exchange or reduce relative humidity are used, hyperhydricity as well as STN were reduced (Fig. 3b), while the use of Gelrite instead of agar improved shoot growth, but increased the incidence of hyperhydricity. Although Matu et al. (2006) did not specifically link aeration problems or hyperhydricity with the incidence of STN in staff tree (Maytenus senegalensis (Lam.) Exell) tissue culture, they described this condition as "a major problem". They improved shoot growth by substituting Gelrite for agar as the gelling agent during shoot multiplication. Offord and Tyler (2009) noted that increased ventilation by employing vented lids for greater transpiration, STN in pink pimelea (Pimelea spicata $\mathrm{R}$. Br.) cultures increased from 38 to $73 \%$ on MS medium and from 18 to $56 \%$ on half-MS medium, but hyperhydricity was observed in both ventilated and unventilated treatments. Compared to cultures on solid medium containing DKW macroelements, MS microelements, $3 \%$ sucrose and $0.44 \mu \mathrm{M} \mathrm{BA}$, cultures of dahlia (Dahlia $x$ hybrida) in liquid culture eliminated STN (De Klerk and ter Brugge 2011). Vibha et al. (2014) reached the same conclusion for North Indian rosewood 
(Dalbergia sissoo Roxb.) cultures, reducing hyperhydricity by adding ammonium sulfate to the medium. In quince (Cydonia oblonga Mill.), Singha et al. (1990) found that long culture periods and infrequent subcultures resulted in both STN and hyperhydricity, as well as leaf necrosis. However, the application of 3 to $18 \mathrm{mM} \mathrm{Ca}^{2+}$ and increasing agar concentration from $0.6 \%$ to $1.2 \%$ reduced the incidence of these two physiological disorders, but also lowered shoot proliferation and shoot fresh and dry weight. McCown and Sellmer (1987) suggested that some poplar genotypes developed hyperhydricity in response to media with high nitrogen (N) levels. Balla and Kirilla (2006) noted STN in in vitro cultures of peach interspecific rootstocks at the rooting phase. One possible reason was the development of hyperhydricity at temperatures exceeding $22{ }^{\circ} \mathrm{C}$ (Balla and Mansvelt 2012). Kataeva et al. (1991) found that the absence of BA in medium resulted in no hyperhydricity, but in high levels of STN, in unrooted apple and tea (Camellia sinensis (L.) Kuntze) shoots and in rooted poplar (Рopulus tremula L. $\times$ P. alba L.) and gerbera (Gerbera jamesonii Bolus ex Hooker f.) plantlets (Table 1). However, when BA was added at $4.4 \mu \mathrm{M}$ into media for apple, hyperhydricity increased to $4 \%$ in cotton-covered vessels ( $18 \%$ in foil-covered vessels), even more at $22.1 \mu \mathrm{M}$ (18\% in cotton-covered vessels and $73 \%$ in foil-covered vessels), and even more at $22.1 \mu \mathrm{M}$ with $5.3 \mu \mathrm{M}$ NAA $(58 \%$ in cotton-covered vessels and $80 \%$ in foil-covered vessels). Had the levels of STN in these four plant species been defined, this would have been an important assessment of the possible link between STN and hyperhydricity.
We recommend the use of culture vessels with improved ventilation and reduced hyperhydricity to reduce the accumulation of ethylene. This would improve $\mathrm{Ca}^{2+}$ flow, ultimately reducing the incidence of STN.

\section{Other factors}

Several studies in the literature have reported the incidence of STN in response to factors that are not linked to nutrients, PGRs, or other factors discussed previously.

Lall et al. (1997) observed that exposure of in vitro Mrs Flanagan's impatiens (Impatiens flanaganiae Hemsl.) plantlets to high light intensity $\left(280 \mu \mathrm{mol} \mathrm{m} \mathrm{m}^{-2} \cdot \mathrm{s}^{-1}\right)$ for 7 weeks induced necrosis in terminal parts, but it was not clear if this was STN. However, Marks and Simpson (1999) also noticed a similar pattern of increased STN in in vitro cultures of disanthus (Disanthus cercidifolius Maxim.) and Northern European hawthorn (Crataegus oxyacantha 'Paul's Scarlet'), but not of three Rhododendron cultivars. In their study, plants were exposed to moderate or high light intensity (55 or $106 \mu \mathrm{mol} \mathrm{m} \mathrm{m}^{-2} \mathrm{~s}^{-1}$ ) and tested against low light intensity (11 or $26 \mu \mathrm{mol} \mathrm{m}^{-2} \mathrm{~s}^{-1}$ ), in culture (Table 2).

In American chestnut genotypes B'ville, Iowa \#2 and VDW, wounding of cuttings did not significantly affect the rate of STN, but promoted rooting, although the level of STN and rooting was intricately dependent on the level of auxin and cytokinin (Xing et al. 1997). Khalafalla and Daffalla (2008) found that scion length and rootstock age impacted the incidence of STN in grafted gum arabic (Acacia senegal

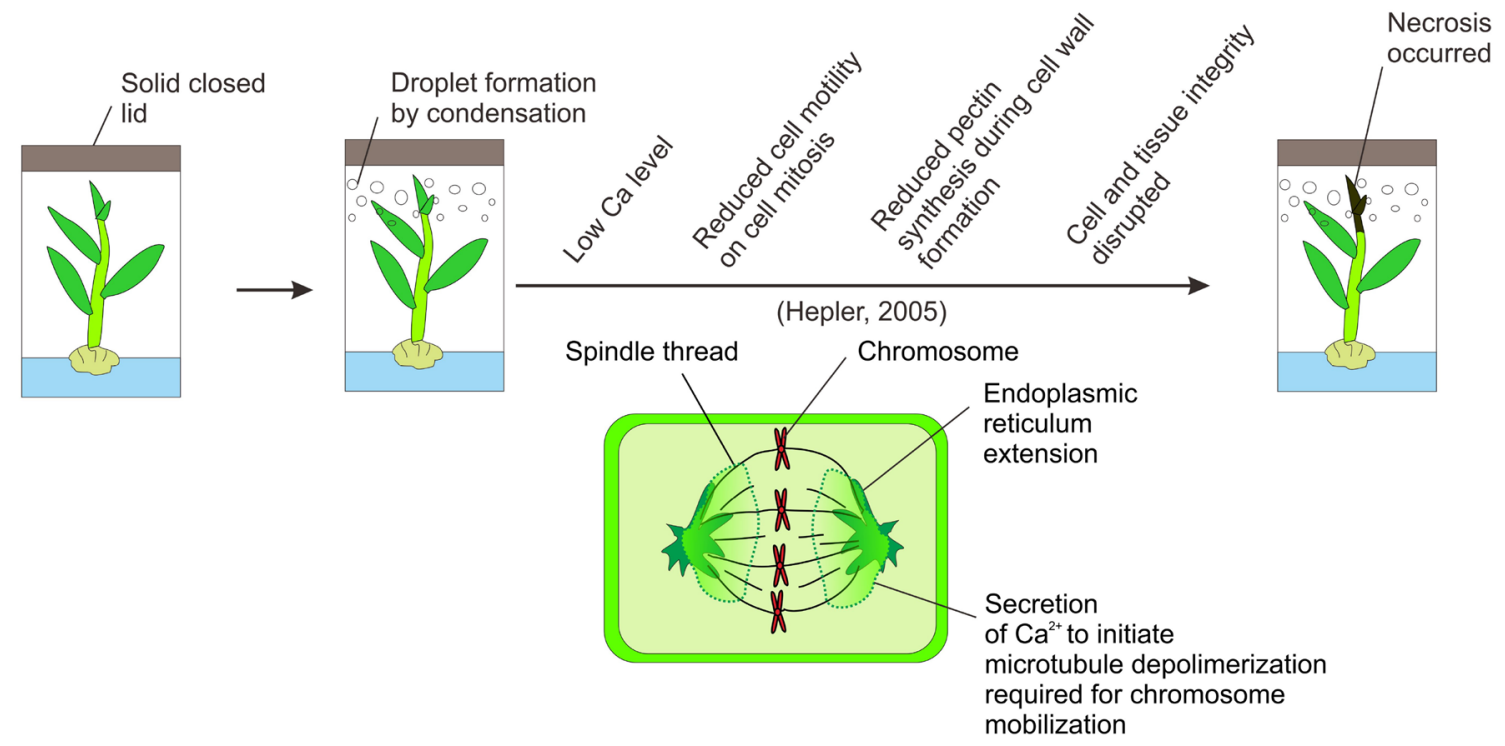

Fig. 3 Schematic diagram depicting how high humidity and reduced transpiration in closed tissue culture vessels may induce shoot tip necrosis (STN). Such growth conditions can induce low levels of calcium $(\mathrm{Ca})$ which in turn reduces cell motility and pectin synthesis, disrupting cell (cell wall or cell membrane) and tissue integrity, and reduce transpiration (Hepler 2005), potentially leading to STN. This biochemical hypothesis has still not yet been tested specifically for STN 
(L.) Willd.) shoot tips. They registered 7\% STN when scions were $2.5-3 \mathrm{~cm}, 27 \%$ when they were $1.5-2 \mathrm{~cm}$, or $14 \%$ when rootstocks were 7 days old $(0 \%$ STN when rootstocks were 14 days old). The incidence of STN in grape cv. Arka Neelamani also depended on the position of the explant on the stock plantlet and its initial weight (Thomas 2000).

The establishment of STN is also influenced by light intensity during shoot multiplication, and other factors such as rootstock age.

\section{Possible mechanisms underlying STN}

\section{Programmed cell death, necrosis, and stress}

It is possible that the underlying mechanisms to explain explant wounding and subsequent tissue browning may be similar. However, since we consider STN to be a physiological response of a living tissue on a developing in vitro plant, rather than a cut explant, we will hereafter only consider the possible factors that might affect STN. The use of chemicals such as antioxidants (e.g., Misra et al. 2010), reduction in light intensity since high light intensity stimulates polyphenol oxidase (Krishna et al. 2008), or the inhibition of phenylpropanoid biosynthesis (Jones and Saxena 2013) may be viable ways to alleviate STN, similar to tissue browning after explant cutting during the establisment of an in vitro culture. When oxidative stress can no longer be controlled, programmed cell death (PCD) develops (Gaspar et al. 2002), which may explain STN. Beckman (2000) further suggested that specialized cells induced cell suberization and lignification as a result of the accumulation of phenolic compounds, thereby strategically stimulating PCD. PCD develops as a function of $\mathrm{H}_{2} \mathrm{O}_{2}$, the "death signal", and in response to other reactive oxygen species (Demidchik 2015). PCD affects several developmental events in plants, including sensescence where proteins, phospholipids and pigments may be degraded (Drury and Gallois 2006; Henmi et al. 2007; Misra et al. 2010; Kacprzyk et al. 2011). Ethylene, which can accumulate in closed tissue culture vessels in vitro, is a strong inducer of leaf senescence and a trigger for PCD (Santner et al. 2009; Trobacher 2009; Park et al. 2016). Moreover, ethylene initiates a signaling pathway, including calcium transport, during the development of aerenchyma, which also plays a role in PCD (Jones 2001). It is still unclear if PCD is involved in, related to, or the cause of STN.

\section{Calcium and calcium signaling}

Ca deficiency is one of the most commonly cited reasons for STN (Table 1). In closed tissue culture vessels, the high relative humidity and reduced transpiration induced low $\mathrm{Ca}^{2+}$ levels, because $\mathrm{Ca}^{2+}$ cannot translocate but must be actively transported (Hepler 2005). This does not permit pectin to be synthesized, impeding the formation of the shoot meristem due to compromised cell integrity and membrane permeability (Martin et al. 2007; Naaz et al. 2014) (Fig. 4). Moreover, $\mathrm{Ca}^{2+}$ serves as a universal secondary messenger in cellular signaling in plants, so the hormonal balance and $\mathrm{Ca}^{2+}$ supply during growth and development may affect each other. There is a correlation between $\mathrm{Ca}^{2+}$ and auxin signaling: auxin induces $\mathrm{Ca}^{2+}$ signals and vice versa, and $\mathrm{Ca}^{2+}$ controls the speed of transport of an auxin (Vanneste and Friml 2013). A high level of auxin might cause excessive ethylene production in jars and change the CK: auxin ratio. As was observed by Busse et al. (2008), STN in potato cultures, which resulted in a loss of apical dominance, was caused by low levels of $\mathrm{Ca}^{2+}$ in medium (Ozgen et al. 2011). This theory was confirmed by two experiments (Ozgen et al. 2011): the addition of a $\mathrm{Ca}^{2+}$ chelator, ethylene glycol tetra acetic acid (EGTA), to medium with sufficient $\mathrm{Ca}^{2+}$ $(2720 \mu \mathrm{M})$ induced the precise same symptoms as low $\mathrm{Ca}^{2+}$ levels, namely STN and axillary shoot formation; in that condition, the supplemental addition of $204 \mu \mathrm{M}$ strontium $\left(\mathrm{Sr}^{2+}\right)$, which is a $\mathrm{Ca}^{2+}$ analog, restored apical dominance. Increasing $\mathrm{Ca}^{2+}$ in medium of several tree species has been shown to alleviate STN (McCown and Sellmer 1987). Cagluconate is an organic form of $\mathrm{Ca}$ that allows $\mathrm{Ca}^{2+}$ to be released into aqueous solutions, explaining why it has occasionally been used to alleviate STN, but it negatively affects shoot growth (Singha et al. 1990; Amalia et al. 2014). We suspect that the use of gas-permeable culture vessels, such as the Vitron or Miracle Pack (Teixeira da Silva et al. 2006), could reduce hyperhydricity, reduce the accumulation of ethylene, increase transpiration and consequently increase the transport of $\mathrm{Ca}^{2+}$ to the shoot apical meristem, although this hypothesis has yet to be tested on in vitro plant cultures displaying STN.

Since the level of the endogenously accessible $\mathrm{Ca}^{2+}$ depends not only on its content in the medium but also on its uptake, it is reasonable to expect that the content of other ions in the medium such as $\mathrm{Mg}^{2+}, \mathrm{K}^{+}$, some microelements or $\mathrm{NH}_{4}^{+}$, which can modify the uptake of $\mathrm{Ca}^{2+}$ from the medium based on nutrient interactions (Fageria 2001), may have an effect on STN. In this sense, Ca deficiency may be relative. The content of mesoelements such as $\mathrm{Ca}^{2+}, \mathrm{Mg}^{2+}$ and $\mathrm{K}^{+}$in the medium modified the rate of the STN in different plant species (Reed et al. 2016; Kovalchuk et al. 2017a, b; details in Table 1). In wild apricot shoot culture, the $\mathrm{NH}_{4}^{+} / \mathrm{Ca}^{2+}$ ratio should be optimally below 0.8 , to minimize STN, specifically $\mathrm{NO}_{3}^{-}>45 \mathrm{mM}$ and $25 \mathrm{mM}<\mathrm{NH}_{3}^{-} \leq 45 \mathrm{mM}+\mathrm{NH}_{4}^{+} / \mathrm{Ca}^{2+} \leq 0.8$ for node 5 (Kovalchuk et al. 2018). In shoot cultures of different pear species, besides the role of various mesoelements like $\mathrm{Ca}^{2+}, \mathrm{Mg}^{2+}$, and $\mathrm{K}^{+}$, the roles of $\mathrm{Fe}^{2+}$ and the proper 
Table 2 Cause-effect (IF-THEN) rules created by neurofuzzy logic indicating the best combination of inputs to alleviate STN in pistachio in vitro cultures

\begin{tabular}{|c|c|c|c|c|}
\hline \multicolumn{4}{|c|}{ Rules } & \multirow[t]{2}{*}{ Membership degree } \\
\hline & & SubModel:1 & & \\
\hline 1 & IF & $\begin{array}{l}\text { EDTA }^{-} \text {is low and } \mathrm{K}^{+} \\
\text {is low }\end{array}$ & THEN & Low (1.00) \\
\hline 2 & & $\begin{array}{l}\text { EDTA }^{-} \text {is low and } \mathrm{K}^{+} \\
\text {is high }\end{array}$ & & Low (1.00) \\
\hline 3 & & $\begin{array}{l}\text { EDTA }^{-} \text {is mid and } \mathrm{K}^{+} \\
\text {is low }\end{array}$ & & Low (1.00) \\
\hline 4 & & $\begin{array}{l}\mathrm{EDTA}^{-} \text {is mid and } \mathrm{K}^{+} \\
\text {is high }\end{array}$ & & Low (1.00) \\
\hline 5 & & $\begin{array}{l}\text { EDTA }^{-} \text {is high and } \mathrm{K}^{+} \\
\text {is low }\end{array}$ & & High (1.00) \\
\hline 6 & & $\begin{array}{l}\text { EDTA }^{-} \text {is high and } \mathrm{K}^{+} \\
\text {is high }\end{array}$ & & High (1.00) \\
\hline & & SubModel:2 & & \\
\hline 7 & IF & $\mathrm{BA}$ is low & THEN & High (1.00) \\
\hline 8 & & $\begin{array}{r}\text { BA is high } \\
\text { SubModel:3 }\end{array}$ & & Low (1.00) \\
\hline 9 & IF & $\mathrm{IF} \mathrm{Cl}^{-}$is low & THEN & High (1.00) \\
\hline 10 & & $\begin{array}{l}\mathrm{IF} \mathrm{Cl}^{-} \text {is high } \\
\text { SubModel:4 }\end{array}$ & & Low (1.00) \\
\hline 11 & IF & Genotype is Ghazvini & THEN & High (0.55) \\
\hline 12 & & $\begin{array}{l}\text { Genotype is UCB-1 } \\
\text { SubModel:5 }\end{array}$ & & Low $(0.93)$ \\
\hline 13 & IF & $\mathrm{Na}^{+}$is low & THEN & Low $(0.78)$ \\
\hline 14 & & $\mathrm{Na}^{+}$is mid & & High (0.94) \\
\hline 15 & & $\mathrm{Na}^{+}$is high & & Low (1.00) \\
\hline
\end{tabular}

Inputs with stronger effects have been highlighted by software (for additional details see Nezami-Alanagh et al. 2019)

concentrations of nitrogen compounds were reported to be involved in the occurrence of STN (Reed et al. 2013, details in Table 1).

In addition, Subbaiah et al. (2000) found that activation of protease, which played a role in PCD induced by anoxia in maize (Zea mays L.) roots, was $\mathrm{Ca}^{2+}$ dependent. The role of $\mathrm{Ca}^{2+}$ in plant stress response and signaling has been detailed in a review by Robertson (2013). Bairu (2008) found that the main problem related to Ca deficiency was not the level of $\mathrm{Ca}^{2+}$ in medium but its limited transport in plantlets due to excess $\mathrm{BO}_{3}^{-}$. Moreover, $\mathrm{Ca}^{2+}$ transport in plants through the xylem sap requires transpiration, which is inhibited by high humidity in the culture vessel, thus the limited mobility of $\mathrm{Ca}^{2+}$ can play a role in the development of STN (Hirschi 2004).

\section{Plant growth regulators}

As indicated above, ethylene is a likely inducer of PCD and thus may be a direct cause of STN in unventilated culture vessels. Table 1 indicates that PGRs have been heavily implicated in STN, mostly CKs during the shoot induction stage, but also the $\mathrm{CK} \times$ auxin interaction during the root induction stage of shoots. For example, the absence or use of low concentrations of CKs was implicated as a reason for the presence of STN since roots are the main source of CKs (Chen et al. 1985), reducing cell division in the shoot apical meristem (Piagnani et al. 1996). The damage to shoot tips reduces the synthesis of auxin because shoot tips are the main site of auxin biosynthesis (Leopold 1975; Aloni et al. 2003; Hopkins and Hüner 2009). Exogenously added CKs can act with different efficiency depending on their structure, the plant species or even the cultivar (Dobránszki and Teixeira da Silva 2010). Application of the highly active $m \mathrm{~T}$ or $m \mathrm{TR}$ (hydroxylated BA derivatives) can delay senescence and can eliminate abnormalities of in vitro cultures, including a reduction of hyperhydricity and STN (Aremu et al. 2012). Similarly, Kumari et al. (2017) found that when $m$ TR was used in the shoot regeneration medium of dwarf wild begonia (Begonia homonyma Steud.), the occurrence of shoot necrosis was reduced to about a half of other regenerants cultured on medium with BA or TDZ. After subculture of regenerated shoots onto elongation medium, STN occurred again at a low frequency (18\%) if previously regenerants had developed on medium with $m \mathrm{TR}$. Bairu et al. (2011) studied the background effects of CK on STN, including an analysis of both endogenous and exogenous CKs and their derivatives, in devil's claw. They found a higher content of total CKs in necrotic shoots than in normal shoots in all studied cases. However, they also detected larger quantities of deactivated forms of CKs such as 9-glucolides in BA-treated and necrotic shoots relative to normal and $m \mathrm{~T}$-treated shoots, suggesting that the occurrence of STN may be due to a change of active CKs to other deactivated products, possibly reversibly, but that can be toxic. $\mathrm{N}^{7}$ and $\mathrm{N}^{9}$ conjugates, which are the inactive forms of BA, are biologically inactive and chemically quite stable, but their conjugation is not fully irreversible (Werbrouck et al. 1996). These conjugates usually accumulate at the base of in vitro shoots, so the active form can be continuously released and cause disorders such as STN (Werbrouck et al. 1996; Strnad et al. 1997). Topolins are hydroxylated forms of BA with high activity in plant tissue culture but they have a different metabolism from that of BA and, therefore, side-effects caused by the release of the active form from inactive BA conjugates can be avoided (reviewed in: Dobránszki and Teixeira da Silva 2010). 


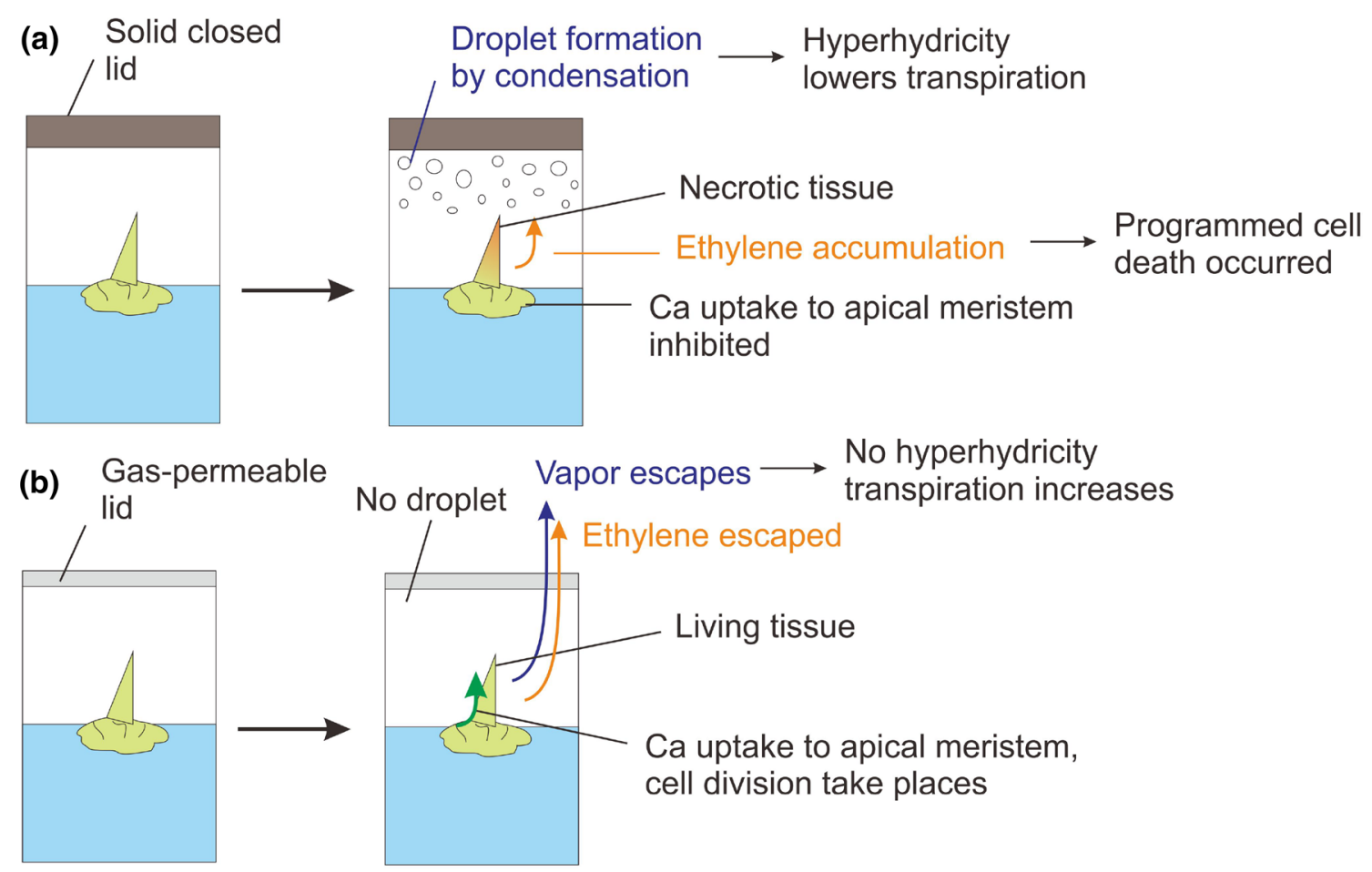

Fig. 4 The impact of hyperhydricity, as a result of poorly ventilated culture vessels, may promote shoot tip necrosis (STN). Schematic representation of the possible mechanisms involved in STN when an in vitro plant culture is established in a closed vessel, causing ethylene to accumulate (a). Schematic representation of the possible meth-

\section{Unmasking the effect of media ingredients on STN using artificial intelligence}

In the 1990s, a wide range of statistical methods for the multivariate analysis of plant cell tissue data were employed, but those studies have some limitations (Gago et al. 2010; Gallego et al. 2011): (i) limited kind of data (qualitative or quantitative) can be analyzed using multivariate analysis, but not nominal or image data; (ii) limited application of linear tools such as ANOVA and regression, since biological responses present a high degree of intra- and inter-individual variation that interacts in a non-linear and non-deterministic way; and (iii) a slump in the use of statistical methods to predict or optimize plant tissue culture. In recent years, several parametric approaches such as response surface methodology (RSM), decision trees, Chi-square automatic interaction detector (CHAID), adaptive regression splines and artificial intelligence tools, based on machine learning systems, have been successfully applied to the design of plant tissue media as advanced techniques (Poothong and Reed 2014; Akin et al. 2016,2020). Other computer-based tools based on artificial intelligence tools for understanding the effect of media components on in vitro cultured plants were also ods to reduce hyperhydricity and ethylene accumulation, by employing gas-permeable culture vessels, to ensure the healthy growth of shoot tips in vitro by reducing or eliminating the incidence of STN (b)

explored (Gago et al. 2010; Gallego et al. 2011; Zielińska and Kępczyńska 2013).

Gallego et al. (2011) extensively reviewed the advantages of using artificial neural networks (ANNs) and fuzzy logic, to discover the cause-effect function of various factors on the response of in vitro plantlets. These artificial intelligence tools help researchers to obtain insight of the cause-effect relationships between factors studied (i.e., mineral nutrients) and a wide range of responses (i.e., growth parameters, physiological disorders, etc.). More recently, the combination of DOE with neurofuzzy logic provided them with a powerful tool to obtain a deeper understanding about the effects of culture media composition on different growth parameters (Nezami-Alanagh et al. 2018) and also several physiological disorders, including STN, during micropropagation of two pistachio rootstocks, UCB-1 and Ghazvini (Nezami-Alanagh et al. 2019). Noticeably, in the latter study, STN was successfully modeled with the help of neurofuzzy logic tools, being affected by complex interactions of ions, cytokinin (BA), and genotype. Those results indicated that in pistachio in vitro cultures, STN is caused by the effect of several factors (individually or in interaction), splitting these effects into five sub-models: (1) the complex interaction of ethylenediaminetetraacetic acid 
$\left(\mathrm{EDTA}^{-}\right) \times \mathrm{K}^{+}$as the strongest effect, followed by (2) BA, (3) $\mathrm{Cl}^{-}$, (4) genotype and (5) $\mathrm{Na}^{+}$(Fig. 5). The cause-effect induced by STN-related "factors" can be easily understood by several 'IF-THEN' rules presented in Table 3, which can be summarized as follows: (i) the strongest effect of low-mid concentrations of $\mathrm{EDTA}^{-}(0.06<\times<0.39 \mathrm{mM})$, regardless of the $\mathrm{K}^{+}$content (rules 5-6). Furthermore, the lowest STN values are also obtained on media including high amounts of BA $(1.30<x<1.50 \mathrm{mg} / \mathrm{l}$, i.e., $5.72<\times<6.60 \mu \mathrm{M})$ and $\mathrm{Cl}^{-}(9.10<x<17.96 \mathrm{mM}$ (rules 8 and 10). 'UCB-1' shoots were more resistant than 'Ghazvini' rootstock with respect to STN (rules 11-12). Finally, $\mathrm{Na}^{+}$influenced the appearance of STN in pistachio cultures, with lowest STN when a high concentration of $\mathrm{Na}^{+}$is included in the medium (rule $15)$.

In conclusion, these findings assert the importance of applying computer-based tools in order to: (i) create a wellsampled design space with the advantage of saving time and costs, (ii) the possibility of splitting salts to their fundamental ions without ion-confounding concerns, (iii) discovery of key factors that impact the measured parameters, and iv) optimization of new cost-effective culture media for healthy in vitro plant growth.

\section{Conclusion}

The literature on STN in in vitro plant micropropagation exceeds 100 studies. While many authors observed STN, in several cases finding practical solutions to eliminate this physiological condition (64 studies in Table 1), many other studies reported the presence of STN, or a reduction in STN, without providing any exact data. Readers should note that Table 1 and Suppl. Table 1 do not reflect the total of all studies that claimed the existence of STN, only those studies that provided quantitative evidence of this phenomenon. In addition, it is likely that many more studies in the plant tissue culture literature may have observed STN. However, STN tends to be observed as a negative finding, but may have either been referred to in other terms, or not reported at all because the publication of negative results is generally not encouraged in mainstream, including plant science, journals (Teixeira da Silva 2015). Thus, the values that we report may underrepresent the true extent of the occurrence of STN.

In summary, first and foremost, the in vitro factor with the most notable influence is nutrient deficiency, mainly $\mathrm{Ca}, \mathrm{B}$ and $\mathrm{N}$, although there is an interaction with other ions, the ion-confounding effect. The level and type of PGRs in a medium can also impact STN. Other factors that were found to induce STN were the timing of measurements and length of subculture, genotype, choice of basal medium, antioxidants, and possibly humidity, aeration and hyperhydricity.

In Fig. 6, we summarized the mechanisms by which STN can occur based on our current knowledge. The lack or imbalance of different nutrients, inappropriate PGR content, and the lack of antioxidants in medium, as well as high humidity and/or low ventillation in culture vessels are proven causes of STN mainly by affecting the uptake and transport of $\mathrm{Ca}$ from medium, and modifying the endogenous hormonal balance of in vitro plantlets. Ca deficiency in plants can occur either directly, if a low level of $\mathrm{Ca}^{2+}$ is added to the culture medium, or indirectly due to the presence and concentration of other nutrients by modifying $\mathrm{Ca}$ uptake based on nutrient interactions. $\mathrm{Ca}^{2+}$ can activate polyphenol oxidase (PPO) by changing its conformational state (Ruiz et al. 2003) and peroxidase (POD) by inducing cross-linking in the chains of polygalacturonan (Penel et al. 1999). Thus, $\mathrm{Ca}^{2+}$ can inhibit the accumulation of phenolic compounds by stimulating their oxidation and, as a result, it can decrease or inhibit STN, hindering the accumulation

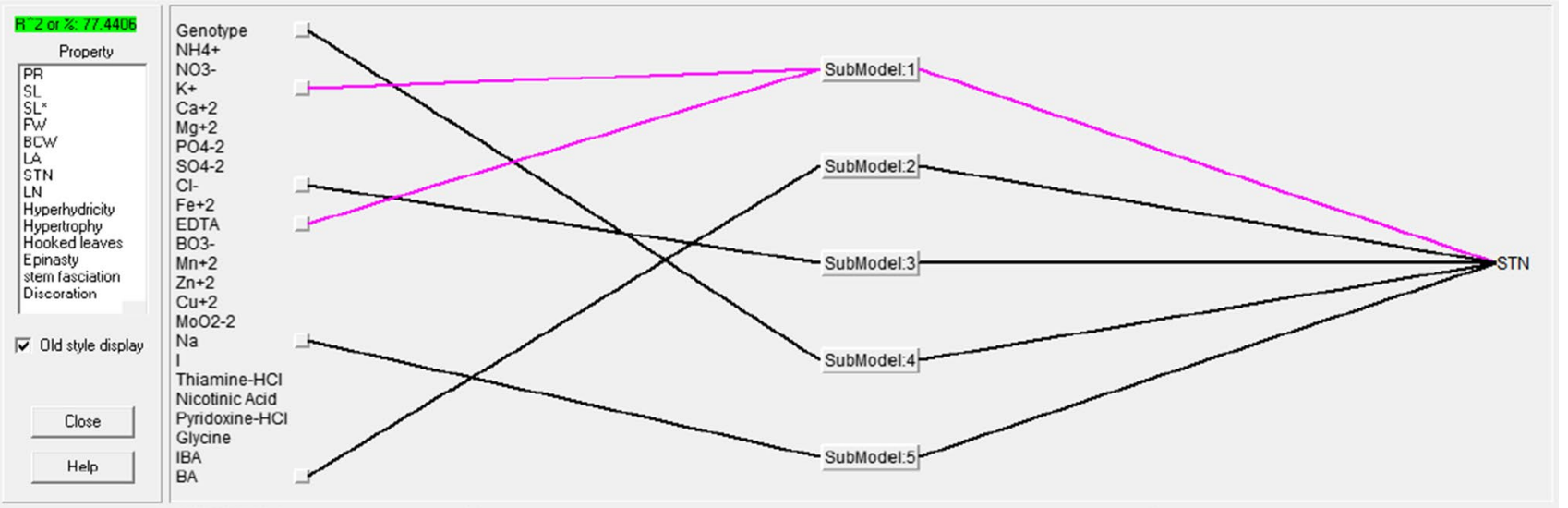

Fig. 5 Graphical representation of critical factors affecting STN extracted by neurofuzzy logic. The inputs with stronger effects are marked in pink 
of phenolic coumpounds and PCD (continuous arrows). Boron acts in two ways when inhibiting STN. A high concentration of $\mathrm{BO}_{3}^{-}$can stimulate the uptake of $\mathrm{Ca}^{2+}$ and helps $\mathrm{Ca}^{2+}$ movement within the plant (continuous arrows). The quantity and form of $\mathrm{N}\left(\mathrm{NH}_{4}^{+}\right.$or $\left.\mathrm{NO}_{3}^{-}\right)$, as well as the ratios of $\mathrm{NH}_{4}^{+} / \mathrm{NO}_{3}^{-}$and $\mathrm{NH}_{4}^{+} / \mathrm{Ca}^{2+}$ affect the occurrence of STN, likely in part through the modification of the ratio of cytokinins to auxins (dotted arrows). The levels of $\mathrm{Cl}^{-}$and gluconate $^{-}$in the medium can affect the level of STN as well, but the mechanisms by which they act are unknown (dotted arrows). The level and type of PGRs added to the medium also affect the occurrence of STN by changing the levels of ethylene, cytokinins, and auxin. The structure of cytokinins added to the culture medium affects the quantity of their active forms and thus the cytokinin to auxin ratio within the plant. A high level of auxin in a plant modifies $\mathrm{Ca}^{2+}$ signaling, while a modified level of $\mathrm{Ca}^{2+}$ in a plant modifies auxin transport (blue arrows). Moreover, a high level of auxin in a plant can act directly and generate the production of ethylene, thereby increasing STN. The addition of different antioxidants into the medium can prevent the accumulation of ethylene, thus inducing STN. If relative humidity is high, or if there is weak or no ventilation in culture vessels, this can lead to increased ethylene production and thus STN. High humidity also modifies $\mathrm{Ca}^{2+}$ transport within a plant causing its low mobility in the xylem and leading to $\mathrm{Ca}$ deficiency in the shoot tip (continuous arrows).

Several possible solutions to eliminating or reducing STN in vitro have been proposed, based on the main factors known for causing STN in vitro (Fig. 6). Despite these proposals, the mechanism(s) remains inconclusive, unexplored, and far from resolved, especially given the wide-ranging, and sometimes contradictory, responses and frequently observed genotype dependence. This review provides, despite not fully understanding the mechanism underlying STN, a more concise and updated summary of studies in STN in vitro with the hope that it will generate new ideas that would allow plant physiologists and molecular biologists to further explore the physiological and genetic mechanisms underlying this disorder.

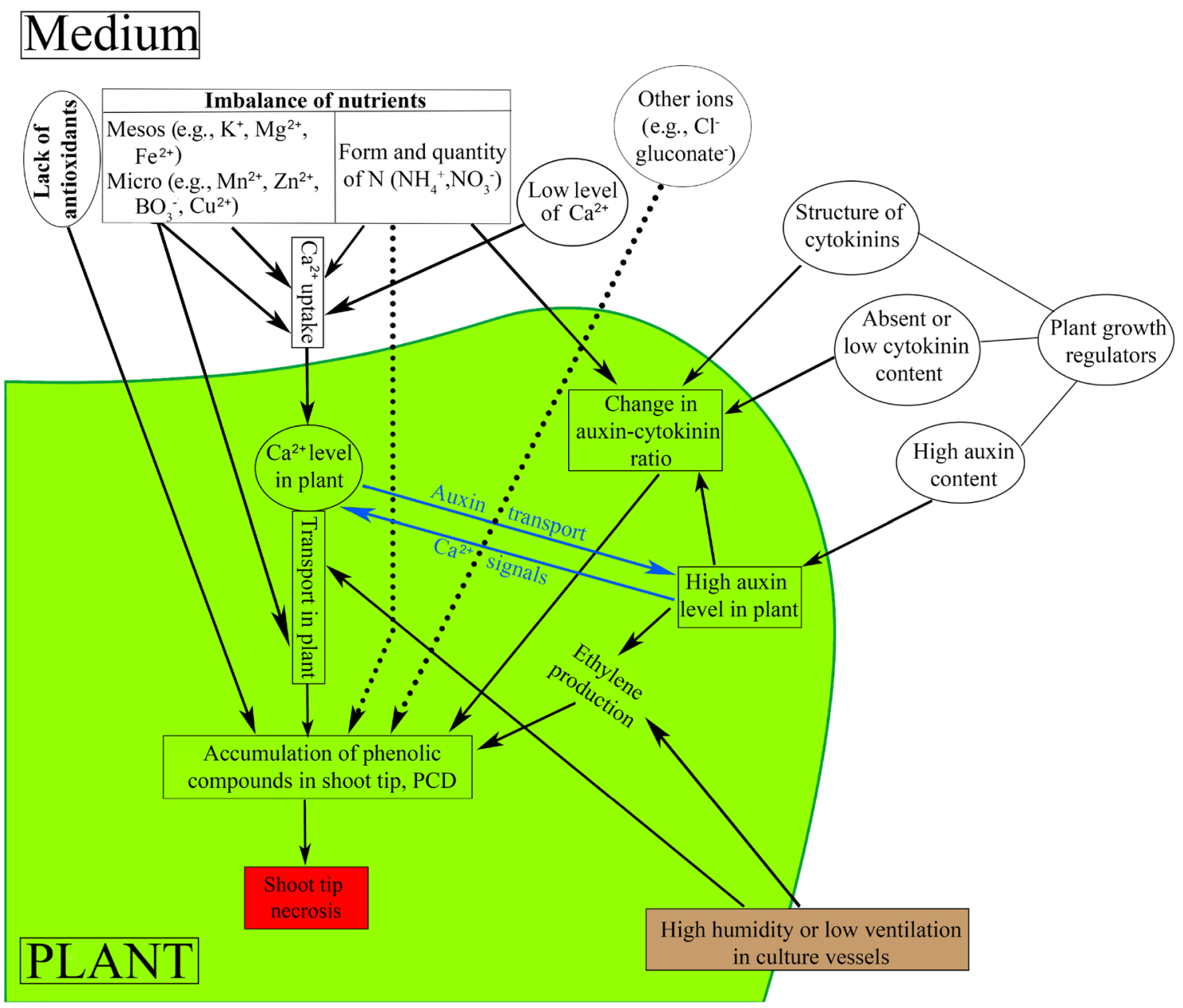

Fig. 6 Schematic diagram showing the overall mechanisms of shoot tip necrosis (STN) in in vitro plants. A detailed description may be found in the text, in "Conclusion" 
Author contribution statement JATdS and MMK conceived the idea and compiled the literature. JATdS wrote the first drafts. In subsequent versions and drafts, all authors contributed equally to ideas, writing, figures, supplements, revisions and corrections. All authors approve the published version and take responsibility for its content.

\begin{abstract}
Acknowledgements The authors thank The American Society for Horticultural Science for kindly providing a scanned copy of the Sha et al. (1985) paper. This research was financed by the Higher Education Institutional Excellence Programme (NKFIH-1150-6/2019) of the Ministry of Innovation and Technology in Hungary, within the framework of the Biotechnology thematic programme of the University of Debrecen. The study and submission for publication were approved by the University of Debrecen (BPTR/DEENK/0008/2019). Esmaeil Nezami-Alanagh thanks the Biotechnology Department at Imam Khomeini International University (IKIU) for their assistance in carrying out a part of the experiment work and also to Science and Technology Park of EastAzarbaijan, Islamic Republic of Iran, for financial support. The Spanish work on STN modeling was funded by Xunta de Galicia, Spain (CITACA Strategic Partnership, Reference: ED431E 2018/07 and REDES, Reference: ED431D-2017/19). The authors also thank Mr. Nicolas Manterola (Laboratorios Green Nova, Casablanca, Chile) for kindly providing the photographs used in Fig. 2. The authors thank the input, critique, and valuable suggestions made by six anonymous peer reviewers.
\end{abstract}

Funding Open access funding provided by University of Debrecen.

\section{Compliance with ethical standards}

Conflict of interest The authors have no conflicts of interest of relevance to this paper to declare.

Open Access This article is licensed under a Creative Commons Attribution 4.0 International License, which permits use, sharing, adaptation, distribution and reproduction in any medium or format, as long as you give appropriate credit to the original author(s) and the source, provide a link to the Creative Commons licence, and indicate if changes were made. The images or other third party material in this article are included in the article's Creative Commons licence, unless indicated otherwise in a credit line to the material. If material is not included in the article's Creative Commons licence and your intended use is not permitted by statutory regulation or exceeds the permitted use, you will need to obtain permission directly from the copyright holder. To view a copy of this licence, visit http://creativecommons.org/licenses/by/4.0/.

\section{References}

Abdulnour JE, Donnelly DJ, Barthakur NN (2000) The effect of boron on calcium uptake and growth in micropropagated potato plantlets. Potato Res 43:287-295. https://doi.org/10.1007/BF023 58088

Abousalim A, Mantell SH (1994) A practical method for alleviating shoot-tip necrosis symptoms in in vitro shoot cultures of Pistacia vera cv. Mateur J Hortic Sci 69:357-365. https://doi. org/10.1080/14620316.1994.11516465
Ahmed ZFR, Palta JP (2017a) Hormone-like action of a natural lipid, lysophosphatidylethanolamine: a comparison with auxin. Acta Hortic 1187:107-114. https://doi.org/10.17660/ActaHortic 2017.1187.13

Ahmed ZFR, Palta JP (2017b) Significant variations in mineral composition among agar sources: implications in nutrition and abiotic stress studies that use in vitro culture. Acta Hortic 1187:115-122. https://doi.org/10.17660/ActaHortic.2017.1187.14

Akin M, Eyduran SP, Eyduran E, Reed BM (2020) Analysis of macro nutrient related growth responses using multivariate adaptive regression splines. Plant Cell Tiss Org Cult 140:661-670. https ://doi.org/10.1007/s11240-019-01763-8

Akin M, Eyduran E, Reed BM (2016) Use of RSM and CHAID data mining algorithm for predicting mineral nutrition of hazelnut. Plant Cell Tiss Org Cult 128:303-316. https://doi.org/10.1007/ s11240-016-1110-6

Alderson PG, Harbour MA, Patience PA (1987) Micropropagation of Prunus tenella cv Firehill. Acta Hortic 212:463-468. https://doi. org/10.17660/ActaHortic.1987.212.69

Alegre J, Nisa M, Ramírez Martín N, Cuevas A, Ruiz-Galea M, Celestino C, Tello ML, Toribio M (2015) Micropropagation of mature Platanus $\times$ hispanica trees by axillary shoot proliferation. Acta Hortic 1083:353-360. https://doi.org/10.17660/ActaHortic .2015.1083.44

Aloni R, Schwalm K, Langhans M, Ullrich CI (2003) Gradual shifts in sites of free-auxin production during leaf-primordium develpoment and their role in vascular differentiation and leaf morphogenesis in Arabidopsis. Planta 216:841-853. https://doi. org/10.1007/s00425-002-0937-8

Amalia F, Debnath SC, Yeoung YR (2014) Effects of calcium gluconate and ascorbic acid on controlling shoot necrosis during micropropagation of primocane-fruiting raspberry (Rubus idaeus L.) cultivars. Afr J Biotechnol 13:4361-4368. https:// doi.org/10.5897/AJB2014.14201

Amin MN, Jaiswal VS (1988) Micropropagation as an aid to rapid cloning of a guava cultivar. Sci Hortic 36:89-95. https://doi. org/10.1016/0304-4238(88)90010-6

Amo-Marco JB, Lledo MD (1996) In vitro propagation of Salix tarraconensis Pau ex Font Quer, an endemic and threatened plant. Vitro Cell Dev Biol Plant 32:42-46. https://doi.org/10.1007/ BF02823012

Anderson WC (1975) Propagation of rhododendrons by tissue culture: I. Development of a culture medium for multiplication of shoots. Comb Proc Int Plant Prop Soc 25:129-135

Anderson WC (1984) A revised tissue culture medium for shoot multiplication of Rhododendron. J Am Soc Hort Sci 109:343-347

Aremu AO, Bairu MW, Doležal K, Finnie JF, van Staden J (2012) Topolins: a panacea to plant tissue culture challenges? Plant Cell Tissue Organ Cult 108:1-16. https://doi.org/10.1007/ s11240-011-0007-7

Arora K, Sharma M, Srivastava J, Ranade SA, Sharma AK (2010) Rapid in vitro cloning of a 40-year-old tree of Azadirachta indica A. Juss (Neem) employing nodal stem segments. Agrofor Syst 78:53-63. https://doi.org/10.1007/s10457-009-9230-1

Bairu MW, Jain N, Stirk WA, Doležal K, van Staden J (2009a) Solving the problem of shoot-tip necrosis in Harpagophytum procumbens by changing the cytokinin types, calcium and boron concentrations in the medium. S Afr J Bot 75:122-127. https://doi.org/10.1016/j.sajb.2008.08.006

Bairu MW, Novák O, Doležal K, van Staden J (2011) Changes in endogenous cytokinin profiles in micropropagated Harpagophytum procumbens in relation to shoot-tip necrosis and cytokinin treatments. Plant Growth Regul 63:105-114. https://doi. org/10.1007/s10725-010-9558-6

Bairu MW, Stirk WA, van Staden J (2009b) Factors contributing to in vitro shoot-tip necrosis and their physiological 
interactions. Plant Cell Tissue Organ Cult 98:239-248. https ://doi.org/10.1007/s11240-009-9560-8

Bairu MW (2008) Characterization and control of micropropagation problems in aloe, devil's claw and banana. PhD thesis, University of Kwa-Zulu Natal, Pietermaritzburg, South Africa, pp 167. https://researchspace.ukzn.ac.za/handle/10413/8315

Balla I, Kirilla Z (2006) Micropropagation of peach rootstocks and cultivars. Acta Hortic 725:511-516. https://doi.org/10.17660/ ActaHortic.2006.725.74

Balla I, Mansvelt L (2012) Micropropagation of peach rootstocks and cultivars. Methods Mol Biol 11013:137-148. https://doi. org/10.1007/978-1-62703-074-8_10

Barghchi M, Alderson PG (1983) In vitro propagation of Pistacia vera $\mathrm{L}$. from seedling tissues. J Hortic Sci 58:435-445. https ://doi.org/10.1080/00221589.1983.11515140

Barghchi M, Alderson PG (1985) In vitro propagation of Pistacia vera $\mathrm{L}$. and the commercial cultivars Ohadi and Kalleghochi. J Hortic Sci 60:423-430. https://doi.org/10.1080/14620 316.1985.11515647

Barghchi M, Alderson PG (1996) The control of shoot tip necrosis in Pistacia vera $\mathrm{L}$. in vitro. Plant Growth Regul 20:31-35. https ://doi.org/10.1007/BF00024054

Baskaran P, Moyo M, van Staden J (2014) In vitro plant regeneration, phenolic compound production and pharmacological activities of Coleonema pulchellum. S Afr J Bot 90:74-79. https://doi. org/10.1016/j.sajb.2013.10.005

Beckman CH (2000) Phenolic-storing cells: keys to programmed cell death and periderm formation in wilt disease resistance and in general defence responses in plants? Physiol Mol Plant Pathol 57:101-110. https://doi.org/10.1006/pmpp.2000.0287

Bhalla PL, Mulwa RMS (2003) Tissue culture and Macadamia propagation. Acta Hortic 616:343-346. https://doi.org/10.17660/ ActaHortic.2003.616.50

Bosela MJ, Michler CH (2008) Media effects on black walnut (Juglans nigra L.) shoot culture growth in vitro: evaluation of multiple nutrient formulations and cytokinin types. Vitro Cell Dev Biol Plant 44:316-329. https://doi.org/10.1007/s11627-008-9114-5

Box GEP, Meyer RD (1986) An analysis for unreplicated fractional factorials. Technometrics 28:11-18. https://doi.org/10.1080/00401 706.1986.10488093

Busse JS, Ozgen S, Palta JP (2008) Influence of root zone calcium on subapical necrosis in potato shoot cultures: localization of injury at the tissue and cellular levels. J Am Soc Hortic Sci 133:653662. https://doi.org/10.21273/JASHS.133.5.653

Cardoso JC, Teixeira da Silva JA (2013) Micropropagation of Zeyheria montana Mart. (Bignoniaceae), an endangered endemic medicinal species from the Brazilian cerrado biome. Vitro Cell Dev Biol Plant 49:710-716. https://doi.org/10.1007/s1162 7-013-9558-0

Cardoso JC, Gerald LTC, Teixeira da Silva JA (2018) Micropropagation in the twenty-first century. In: Loyola-Vargas VM, OchoaAlejo N (Eds) Plant cell culture protocols, methods in molecular biology. Vol. 1815, Humana Press, New York, pp. 17-46. https ://doi.org/10.1007/978-1-4939-8594-4_2

Cellárová E, Kimáková K, Brutovská R (1992) Multiple shoot formation and phenotypic changes of R0 regenerants in Hypericum perforatum L. Acta Biotechnol 12:445-452. https://doi. org/10.1002/abio.370120602

Chen C-M, Ertl JR, Leisner SM, Chang C-C (1985) Localization of cytokinin biosynthetic sites in pea plants and carrot roots. Plant Physiol 78:510-513. https://doi.org/10.1104/pp.78.3.510

Cheng TY (1975) Adventitious bud formation in culture of Douglas fir (Pseudotsuga menziensii (Mirb.) Franco). Plant Sci Lett 5:97102. https://doi.org/10.1016/0304-4211(75)90049-8

Chiruvella KK, Mohammed A, Dampuri G, Ghanta RG (2011) In vitro shoot regeneration and control of shoot tip necrosis in tissue cultures of Soymida febrifuga (Roxb.) A. Juss Plant Tiss Cult Biotechnol 21:11-25. https://doi.org/10.3329/ptcb.v21i1.9559

Chiruvella KK, Mohammed A, Ghanta RG (2014) Phenotypic aberrations during micropropagation of Soymida febrifuga (Roxb.) Adr. Juss. Not Sci Biol 6:99-104. https://doi.org/10.15835/nsb619202

Christensen B, Sriskandarajah S, Serek M, Müller R (2008) In vitro culture of Hibiscus rosa-sinensis L.: influence of iron, calcium and BAP on establishment and multiplication. Plant Cell Tiss Org Cult 93:151-161. https://doi.org/10.1007/s11240-008-9354-4

Compton ME, Preece JE (1988) Response of tobacco callus to shoot tip exudation from five species. HortScience 23:208-210

Dangi B, Khurana-Kaul V, Kothari SL, Kachhwaha S (2014) Micropropagtion of Terminalia bellerica from nodal explants of mature tree and assessment of genetic fidelity using ISSR and RAPD markers. Physiol Mol Biol Plants 20:509-516. https://doi. org/10.1007/s12298-014-0247-1

Daud N, Faizal A, Geelen D (2013) Adventitious rooting of Jatropha curcas L. is stimulated by phloroglucinol and by red LED light. Vitro Cell Dev Biol Plant 49:183-190. https://doi.org/10.1007/ s11627-012-9486-4

De Block M (1990) Factors influencing the tissue culture and the Agrobacterium tumefaciens-mediated transformation of hybrid aspen and poplar clones. Plant Physiol 93:1110-1116. https:// doi.org/10.1104/pp.93.3.1110

De Klerk G-J, ter Brugge J (2011) Micropropagation of dahlia in static liquid medium using slow-release tools of medium ingredients. Sci Hortic 127:542-547. https://doi.org/10.1016/j.scien ta.2010.11.015

Demidchik V (2015) Mechanisms of oxidative stress in plants: from classical chemistry to cell biology. Environ Exp Bot 109:212228. https://doi.org/10.1016/j.envexpbot.2014.06.021

Dewir YH, Nurmansyah NY, Teixeira da Silva JA (2018) Thidiazuron-induced abnormalities in plant tissue cultures. Plant Cell Rep 37:1451-1470. https://doi.org/10.1007/s0029 9-018-2326-1

Diro M, van Staden J (2005) The type of explant plays a determining role in the micropropagation of Ensete ventricosum. S Afr J Bot 71:154-159. https://doi.org/10.1016/S0254-6299(15)30127-7

Dobránszki J, Teixeira da Silva JA (2010) Micropropagation of applea review. Biotechnol Adv 28:462-488. https://doi.org/10.1016/j. biotechadv.2010.02.008

Dolcet-Sanjuan R, Claveria E (1995) Improved shoot-tip micropropagation of Pistacia vera L. and the beneficial effects of methyl jasmonate. J Am Soc Hortic Sci 120:938-942. https://doi. org/10.21273/JASHS.120.6.938

Driver JA, Kuniyuki AH (1984) In vitro propagation of Paradox walnut rootstock. Hort Sci 19:507-509

Drury GE, Gallois P (2006) Programmed cell death in plants and flowers. In: Teixeira da Silva JA (ed) Floric ornam biotechnol. Global Science Books, Isleworth, pp 141-156

Fageria VD (2001) Nutrient interactions in crop plants. J Plant Nutr 24:1269-1290. https://doi.org/10.1081/PLN-100106981

Fox RL, Albrecht WA (1958) Calcium-boron interaction demonstrated by Lemna minor on clay suspensions elements. Res Bull Univ Miss Agr Expt Sta 663:15

Gago J, Landín M, Gallego PP (2010) Artificial neural networks modeling the in vitro rhizogenesis and acclimatization of Vitis vinifera L. J Plant Physiol 167:1226-1231. https://doi.org/10.1016/j. jplph.2010.04.008

Gago J, Martínez-Núñez L, Landín M, Flexas J, Gallego PP (2014) Modeling the effects of light and sucrose on in vitro propagated plants: a multiscale system analysis using artificial intelligence technology. PLoS ONE 9:e85989. https://doi.org/10.1371/journ al.pone.0085989

Gallego PP, Gago J, Landin M (2011) Artificial neural networks technology to model and predict plant biology process. In: Suzuki K 
(ed) Artificial neural networks-methodological advances and biomedical applications. Intech, Rijeka, pp 197-216

Gamborg OL, Miller RA, Ojima K (1968) Nutrient requirements of suspension cultures of soybean root cells. Exp Cell Res 50:151158. https://doi.org/10.1016/0014-4827(68)90403-5

García E, Lorente P, Marín JA, Andreu P, Arbeloa A (2011) Factors affecting shoot-tip necrosis of Pistacia vera $\mathrm{L}$. shoots cultured in vitro. Inf Téc Econ Agrar 107:315-323

Gaspar T, Franck T, Bisbis B, Kevers C, Jouve L, Hausman JF, Dommes J (2002) Concepts in plant stress physiology: application to plant tissue cultures. Plant Growth Regul 37:263-285. https://doi.org/10.1023/A:1020835304842

Gomes F, Simões M, Lopes ML, Canhoto JM (2010) Effect of plant growth regulators and genotype on the micropropagation of adult trees of Arbutus unedo L. (strawberry tree). New Biotechnol 27:882-892. https://doi.org/10.1016/j.nbt.2010.02.009

Grigoriadou K, Leventakis N, Vasilakakis M (2000) Effects of various culture conditions on proliferation and shoot tip necrosis in pear cultivars 'Williams's' and 'Highland' grown in vitro. Acta Hortic 520:103-108. https://doi.org/10.17660/ActaHortic.2000.520.10

Guha S, Usha Rao I (2012) Nitric oxide promoted rhizome induction in Cymbidium shoot buds under magnesium deficiency. Biol Plant 56:227-236. https://doi.org/10.1007/s10535-012-0081-7

Hassanein AM, Salem JM, Faheed FA, El-nagish A (2018) Effect of anti-ethylene compounds on isoenzyme patterns and genome stability during long term culture of Moringa oleifera. Plant Cell Tiss Org Cult 132:201-212. https://doi.org/10.1007/s1124 0-017-1326-0

Henmi K, Yanagida M, Ogawa K (2007) Roles of reactive oxygen species and glutathione in plant development. Int J Plant Dev Biol 1:185-193

Hepler PK (2005) Calcium: a central regulator of plant growth and development. Plant Cell 17:2142-2155. https://doi.org/10.1105/ tpc. 105.032508

Hirschi KD (2004) The calcium conundrum. Both versatile nutrient and specific signal. Plant Physiol 136:2438-2442. https://doi. org/10.1104/pp.104.046490

Hopkins WG, Hüner NPA (2009) Hormones I: Auxins. In: Hopkins WG, Hüner NPA (eds) Introduction to plant physiology, 4th edn. Wiley, USA, pp 305-321

Hsia C-N, Korban SS (1996) Factors affecting in vitro establishment and shoot proliferation of Rosa hybrida L. and Rosa Chinensis minima. Vitro Cell Dev Biol Plant 32:217-222. https://doi. org/10.1007/BF02822690

Isah T (2015) Adjustments to in vitro culture conditions and associated anomalies in plants. Acta Biol Cracov Bot 57:9-28. https://doi. org/10.1515/abcsb-2015-0026

Jain N, Bairu MW, Stirk WA, van Staden J (2009) The effect of medium, carbon source and explant on regeneration and control of shoot-tip necrosis in Harpagophytum procumbens. S Afr J Bot 75:117-121. https://doi.org/10.1016/j.sajb.2008.08.005

Jaiswal S, Arya S, Kant T (2013) Role of various additives in controlling shoot tip necrosis of Pterocarpus marsupium Roxb.-a multipurpose leguminous tree. J Phytol Res 26:43-46

Jamshidi S, Yadollahi A, Ahmadi H, Arab MM, Eftekhari M (2016) Predicting in vitro culture medium macro-nutrients composition for pear rootstocks using regression analysis and neural network models. Front Plant Sci 7:1-12. https://doi.org/10.3389/ fpls.2016.00274

Jones AM (2001) Programmed cell death in development and defense. Plant Physiol 125:94-97. https://doi.org/10.1104/pp.125.1.94

Jones AMP, Saxena PK (2013) Inhibition of phenylpropanoid biosynthesis in Artemisia annua L.: a novel approach to reduce oxidative browning in plant tissue culture. PLoS ONE 8:e76802. https ://doi.org/10.1371/journal.pone.0076802
Kacprzyk J, Daly CT, McCabe PF (2011) The botanical dance of death: programmed cell death in plants. Adv Bot Res 60:169-261. https ://doi.org/10.1016/B978-0-12-385851-1.00004-4

Karhu ST (1997) Axillary shoot proliferation of blue honeysuckle. Plant Cell Tiss Org Cult 48:195-201. https://doi.org/10.1023/A:10058 42022064

Kataeva NV, Alexandrova IG, Butenko RG, Dragavtceva EV (1991) Effect of applied and internal hormones on vitrification and apical necrosis of different plants cultured in vitro. Plant Cell Tiss Org Cult 27:149-154. https://doi.org/10.1007/BF00041283

Kermani SA, Hokmabadi H, Jahromi MG (2017) The evaluation of the effect of multiwall carbon nano tube (MWCNT) on in vitro proliferation and shoot tip necrosis of pistachio rootstock UCB-1 (Pistacia integrima $\times$ P. atlantica). J Nut 8:49-59. https://doi. org/10.22034/jon.2017.530392

Khalafalla MM, Daffalla HM (2008) In vitro micropropagation and micrografting of gum arabic tree [Acacia senegal (L.) Wild]. Int J Sustain Crop Prod 3:19-27

Kishore K, Patnaik S, Shukla AK (2015) Optimization of method to alleviate in vitro shoot tip necrosis in Trichosanthes dioica Roxb. Ind J Biotechnol 14:107-111

Koubouris G, Vasilakakis M (2006) Improvement of in vitro propagation of apricot cultivar 'Bebecou'. Plant Cell Tiss Org Cult 85:173-180. https://doi.org/10.1007/s11240-005-9066-y

Kovalchuk IY, Mukhitdinova Z, Turdiyev T, Madiyeva G, Akin M, Eyduran E, Reed BM (2017a) Modeling some mineral nutrient requirements for micropropagated wild apricot shoot cultures. Plant Cell Tiss Org Cult 129:325-335. https://doi.org/10.1007/ s11240-017-1180-0

Kovalchuk IY, Mukhitdinova Z, Turdiyev T, Madiyeva G, Akin M, Eyduran E, Reed BM (2018) Nitrogen ions and nitrogen ion proportions impact the growth of apricot (Prunus armeniaca) shoot cultures. Plant Cell Tiss Org Cult 133:263-273. https:// doi.org/10.1007/s11240-018-1379-8

Kovalchuk IY, Mukhitdinova ZR, Turdiyev TT, Madiyeva GA, Reed BM (2017b) Optimization of in vitro growth medium for a wild Kazakhstan apricot, Prunus armeniaca. Acta Hortic 1155:193200. https://doi.org/10.17660/ActaHortic.2017.1155.27

Krishna H, Sairam RK, Singh SK, Patel VB, Sharma RR, Grover M, Nain L, Sachdev A (2008) Mango explant browning: effect of ontogenic age, mycorrhization and pre-treatments. Sci Hortic 118:132-138. https://doi.org/10.1016/j.scienta.2008.05.040

Kulkarni KR, D’Souza L (2000) Control of in vitro shoot tip necrosis in Butea monosperma. Curr Sci 78:125-126

Kumar PP, Lakshmanan P, Thorpe TA (1998) Regulation of morphogenesis in plant tissue culture by ethylene. Vitro Cell Dev Biol Plant 34:94-103. https://doi.org/10.1007/BF02822771

Kumar S, Singh H, Pandey V, Singh BD (2016) In vitro multiplication of pointed gourd (Trichosanthes dioica) through nodal explant culture, and testing the genetic fidelity of micropropagated plants using RAPD markers. Indian J Biotechnol 15:581-588

Kumari A, Baskaran P, van Staden J (2017) In vitro regeneration of Begonia homonyma - a threatened plant. S Afr J Bot 109:174177. https://doi.org/10.1016/j.sajb.2016.12.027

Kurup SS, Purayil FT, Alkhaili MMS, Tawfik NH, Cheruth AJ, Kabshawi M, Subramaniam S (2018) Thidiazuron (TDZ) induced organogenesis and clonal fidelity studies in Haloxylon persicum (Bunge ex Boiss \& Buhse): an endangered desert tree species. Physiol Mol Biol Plant 24:683-692. https://doi.org/10.1007/ s12298-018-0532-5

Lai C-C, Lin H-M, Nalawade SM, Fang W, Tsay H-S (2005) Hyperhydricity in shoot cultures of Scrophularia yoshimurae can be effectively reduced by ventilation of culture vessels. J Plant Physiol 162:355-361. https://doi.org/10.1016/j.jplph.2004.07.015

Lakshmi Sita G, Raghava Swamy BV (1993) Regeneration of plantlets from leaf disc cultures of rosewood: control of leaf 
abscission and shoot tip necrosis. Plant Sci 88:107-112. https:// doi.org/10.1016/0168-9452(93)90115-G

Lall N, Bosa A, Nikolova RV (1997) Morphological characteristics of impatiens flanaganiae Hemsl. grown under different light conditions. S Afr J Bot 63:216-222. https://doi.org/10.1016/S0254 $-6299(15) 30747-X$

Leopold AC (1975) Part II. Growth regulation. In: Leopold AC, Kriedemann PE (eds) Plant growth and development, 2nd edn. McGraw-Hill Book Company, USA, pp 109-222

Lin G-Z, Zhao X-M, Hong S-K, Lian Y (2011) Somatic embryogenesis and shoot organogenesis in the medicinal plant Pulsatilla koreana Nakai. Plant Cell Tiss Org Cult 106:93-103. https://doi. org/10.1007/s11240-010-9897-z

Linington IM (1991) In vitro propagation of Dipterocarpus alatus and Dipterocarpus intricatus. Plant Cell Tiss Org Cult 27:81-88. https://doi.org/10.1007/BF00048211

Linsmaier EM, Skoog F (1965) Organic growth factor requirements of tobacco tissue cultures. Physiol Plant 18:100-127. https://doi. org/10.1111/j.1399-3054.1965.tb06874.x

Lišková D, Kollárová K, Kučerová D, Vatehová Z, Zelko I, Lux A, van Staden J (2016) Alternatives to improve long-term cultures of Harpagophytum procumbens in vitro. S Afr J Bot 104:55-60. https://doi.org/10.1016/j.sajb.2015.10.008

Lloyd G, McCown B (1980) Commercially-feasible micropropagation of mountain laurel, Kalmia latifolia, by use of shoot-tip culture. Comb Proc Intl Plant Prop Soc 30:421-427

Machado MP, da Silva ALL, Biasi LA, Deschamps C, Filho JCB, Zanette $F$ (2014) Influence of calcium content of tissue on hyperhydricity and shoot-tip necrosis of in vitro regenerated shoots of Lavandula angustifolia Mill. Braz Arch Biol Technol 57:636643. https://doi.org/10.1590/S1516-8913201402165

Mackay WA, Tipton JL, Thompson GA (1995) Micropropagation of Mexican redbud, Cercis canadensis var. mexicana. Plant Cell Tiss Org Cult 43:295-299. https://doi.org/10.1007/BF00039959

Marks TR, Simpson SE (1999) Effect of irradiance on shoot development in vitro. Plant Growth Regul 28:133-142. https://doi. org/10.1023/A:1006276724956

Martin KP, Zhang CL, Slater A, Madassery J (2007) Control of shoot necrosis and plant death during micro-propagation of banana and plantains (Musa spp.). Plant Cell Tiss Org Cult 88:51-59. https ://doi.org/10.1007/s11240-006-9177-0

Martinelli A (1988) Use of "in vitro" techniques for selection and cloning of different Pistacia species. Acta Hortic 227:436-437. https ://doi.org/10.17660/ActaHortic.1988.227.85

Martínez MT, Corredoira E, Vieitez AM, Cernadas MJ, Montenegro R, Ballester A, Vieitez FJ, San José MC (2017) Micropropagation of mature Quercus ilex $\mathrm{L}$. trees by axillary budding. Plant Cell Tiss Org Cult 131:499-512. https://doi.org/10.1007/s1124 0-017-1300-x

Marín JA, García E, Lorente P, Andreu P, Arbeloa A (2016) A novel approach for propagation of recalcitrant pistachio cultivars that sidesteps rooting by ex vitro grafting of tissue cultured shoot tips. Plant Cell Tiss Org Cult 124:191-200. https://doi.org/10.1007/ s11240-015-0871-7

Mason GF, Guttridge CG (1974) The role of calcium, boron and some divalent ions in leaf tipburn of strawberry. Sci Hortic 2:299-308. https://doi.org/10.1016/0304-4238(74)90039-9

Mason GF, Guttridge CG (1975) The influence of relative humidity and nutrition on leaf tipburn of strawberry. Sci Hortic 3:339-349. https://doi.org/10.1016/0304-4238(75)90048-5

Matu ENN, Lindsey KLL, van Staden J (2006) Micropropagation of Maytenus senegalensis (Lam.) Excell. S Afr J Bot 72:409-415. https://doi.org/10.1016/j.sajb.2005.11.005

McCown BH, Sellmer JC (1987) General media and vessels suitable for woody plant culture. In: Bonga JM, Durzan D (eds) Cell and tissue culture in forestry. Springer, The Netherlands, pp. 4-16. https://doi.org/10.1007/978-94-017-0994-1_2

Millington WF (1963) Shoot tip abortion in Ulmus americana. Am J Bot 50:371-378. https://doi.org/10.1002/j.1537-2197.1963. tb07205.x

Mirabbasi SM, Hosseinpour B (2014) Prevention of shoot tip necrosis, hyperhydricity and callus production associated with in vitro shoot culture of Ulmus glabra. J Novel Appl Sci 3:683-689

Misra P, Chakrabarty D (2009) Clonal propagation of Rosa clinophylla Thory. through axillary bud culture. Sci Hortic 119:212-216. https://doi.org/10.1016/j.scienta.2008.07.028

Misra P, Toppo DD, Gupta N, Chakrabarty D, Tuli R (2010) Effect of antioxidants and associate changes in antioxidant enzymes in controlling browning and necrosis of proliferating shoots of elite Jatropha curcas L. Biomass Bioenergy 34:1861-1869. https:// doi.org/10.1016/j.biombioe.2010.07.027

Moura M (1998) Conservation of Hypericum foliosum Alton, an endemic Azorean species, by micropropagation. Vitro Cell Dev Biol Plant 34:244-248. https://doi.org/10.1007/BF02822715

Mubina N, Hoque M, Sarker R (2018) In vitro regeneration and over expression of pea DNA helicase 45 (PDH45) gene into the local cultivars of chickpea (Cicer arietinum L.) through Agrobacterium-mediated genetic transformation. Plant Tissue Cult Biotechnol 28:125-140. https://doi.org/10.3329/ptcb.v28i1.37204

Mulwa RMS, Bhalla PL (2000) In vitro shoot multiplication of Macadamia tetraphylla L. Johnson J Hortic Sci Biotechnol 75:1-5. https://doi.org/10.1080/14620316.2000.11511192

Murashige T, Skoog F (1962) A revised medium for rapid growth and bioassays with tobacco tissue cultures. Physiol Plant 15:473-497. https://doi.org/10.1111/j.1399-3054.1962.tb08052.x

Mythili JB, Thomas P (1999) Micropropagation of pointed gourd (Trichosanthes dioica Roxb.). Sci Hortic 79:87-90. https://doi. org/10.1016/S0304-4238(98)00201-5

Naaz A, Shahzad A, Anis M (2014) Effect of adenine sulphate interaction on growth and development of shoot regeneration and inhibition of shoot tip necrosis under in vitro condition in adult Syzygium cumini L.- - a multipurpose tree. Appl Biochem Biotechnol 173:90-102. https://doi.org/10.1007/s12010-014-0797-2

Nagahatenna DSK, Peiris SE (2007) In vitro propagation of Hemidesmus indicus (L.) R. Br. (Iramusu) through nodal culture. Trop Agr Res 19:181-192

Nezami SR, Yadollahi A, Hokmabadi H, Eftekhari M (2015) Control of shoot tip necrosis and plant death during in vitro multiplication of Pistachio rootstock UCB1 (Pistacia integrima $\times$ P.atlantica). J Nuts 6:27-35. https://doi.org/10.22034/jon.2015.515646

Nezami-Alanagh E, Garoosi G-A, Haddad R, Maleki S, Landín M, Gallego PP (2014) Design of tissue culture media for efficient Prunusrootstock micropropagation using artificial intelligence models. Plant Cell Tiss Org Cult 117:349-359. https://doi. org/10.1007/s11240-014-0444-1

Nezami-Alanagh E, Garoosi G-A, Landín M, Gallego PP (2018) Combining DOE with neurofuzzy logic for healthy mineral nutrition of Pistachio rootstocks in vitro culture. Front Plant Sci 9:1474. https://doi.org/10.3389/fpls.2018.01474

Nezami-Alanagh E, Garoosi G-A, Landín M, Gallego PP (2019) Computer-based tools provide new insight into the key factors that cause physiological disorders of Pistachio rootstocks cultured in vitro. Sci Rep 9:9740. https://doi.org/10.1038/s41598-01946155-2

Nezami-Alanagh E, Garoosi G-A, Maleki S, Landín M, Gallego PP (2017) Predicting optimal in vitro culture medium for Pistacia vera micropropagation using neural networks models. Plant Cell Tiss Org Cult 129:19-33. https://doi.org/10.1007/s1124 0-016-1152-9 
Niedz RP, Evens TJ (2006) A solution to the problem of ion confounding in experimental biology. Nat Methods 3:417-427. https://doi. org/10.1038/nmeth0606-417

Niedz RP, Evens TJ (2007) Regulating plant tissue growth by mineral nutrition. Vitro Cell Dev Biol Plant 43:370-381. https://doi. org/10.1007/s11627-007-9062-5

Niedz RP, Evens TJ (2016) Design of experiments (DOE)—history, concepts, and relevance to in vitro culture. Vitro Cell Dev Biol Plant 52:547-562. https://doi.org/10.1007/s11627-016-9786-1

Nitsch JP, Nitsch C (1969) Haploid plants from pollen grains. Science 163:85-87. https://doi.org/10.1126/science.163.3862.85

Norton ME, Norton CR (1985) In vitro propagation of Ericaceae: a comparison of the activity of the cytokinins $N^{6}$-benzyladenine and $N^{6}$-isopentenyladenine in shoot proliferation. Sci Hortic 27:335-340. https://doi.org/10.1016/0304-4238(85)90038-X

Oberschelp GPJ, Gonçalves AN (2018) Analysis of nutrient deficiencies affecting in vitro growth and development of Eucalyptus dunnii Maiden. Physiol Mol Biol Plants 24:693-702. https://doi. org/10.1007/s12298-018-0560-1

Offord CA, Tyler JL (2009) In vitro propagation of Pimelea spicata R.Br (Thymelaeaceae), an endangered species of the Sydney region. Aust Plant Cell Tiss Org Cult 98:19-23. https://doi. org/10.1007/s11240-009-9534-x

Ozgen S, Busse JS, Palta JP (2011) Influence of root zone calcium on shoot tip necrosis and apical dominance of potato shoot: simulation of this disorder by ethylene glycol tetra acetic acid and prevention by strontium. Hort Sci 46:1358-1362. https://doi. org/10.21273/HORTSCI.46.10.1358

Papadatou P, Pontikis C, Ephtimiadou E, Lydaki M (1990) Rapid multiplication of guava seedlings by in vitro shoot tip culture. Sci Hortic 45:99-103. https://doi.org/10.1016/0304-4238(90)90072 $-\mathrm{M}$

Parfitt DE, Almehdi AA (1994) Use of a high $\mathrm{CO}_{2}$ atmosphere and medium modifications for the successful micropropagation of pistachio. Sci Hortic 56:321-329. https://doi. org/10.1016/0304-4238(94)90050-7

Parh DK, Conner AJ, Jacobs JME, McNeil DL (1998) Shoot-tip necrosis and alleviation during in vitro culture of Lens culinaris. SABRAO J Breed Genet 30:97-101

Park SW, Jeon JH, Kim HS, Park YM, Aswath C, Joung H (2004) Effect of sealed and vented gaseous microenvironments on the hyperhydricity of potato shoots in vitro. Sci Hortic 99:199205. https://doi.org/10.1016/S0304-4238(03)00097-9

Park JS, Naing AH, Kim CK (2016) Effects of ethylene on shoot initiation, leaf yellowing, and shoot tip necrosis in roses. Plant Cell Tiss Org Cult 127:425-431. https://doi.org/10.1007/s1124 0-016-1066-6

Pasqua G, Manes F, Monacelli B, Natale L, Anselmi S (2002) Effects of the culture medium $\mathrm{pH}$ and ion uptake in in vitro vegetative organogenesis in thin cell layers of tobacco. Plant Sci 162:947-955. https://doi.org/10.1016/S0168-9452(02)00048-1

Penel C, van Cutsem P, Greppin H (1999) Interactions of a plant peroxidase with oligogalacturonides in the presence of calcium ions. Phytochemistry 51:193-198. https://doi.org/10.1016/ S0031-9422(98)00741-9

Phillips GC, Garda M (2019) Plant tissue culture media and practices: an overview. Vitro Cell Dev Biol Plant 55:242-257. https ://doi.org/10.1007/s11627-019-09983-5

Piagnani C, Zocchi G, Mignani I (1996) Influence of $\mathrm{Ca}^{2+}$ and 6-benzyladenine on chestnut (Castanea sativa Mill.) in vitro shoot-tip necrosis. Plant Sci 118:89-95. https://doi. org/10.1016/0168-9452(96)04423-8

Podwyszyńska M, Goszczyńska DM (1998) Effect of inhibitors of ethylene biosynthesis and action, as well as calcium and magnesium on rose shoot rooting, shoot-tip necrosis and leaf senescence in vitro. Acta Physiol Plant 20:91-98. https://doi. org/10.1007/s11738-998-0049-6

Poothong S, Reed BM (2014) Modeling the effects of mineral nutrition for improving growth and development of micropropagated red raspberries. Sci Hortic 165:132-141. https://doi. org/10.1016/j.scienta.2013.10.040

Preece J (1995) Can nutrient salts partially substitute for plant growth regulators? Plant Tiss Cult Biotech 1:26-37

Purnhauser L, Medgyesy P, Czakó M, Dix PJ, Márton L (1987) Stimulation of shoot regeneration in Triticum aestivum and Nicotiana plumbaginifolia Viv. tissue cultures using the ethylene inhibitor $\mathrm{AgNO}_{3}$. Plant Cell Rep 6:1-4. https://doi. org/10.1007/BF00269725

Pérez C, Rodríguez R, Tamés R (1985) "In vitro" filbert (Corylus avellana L.) micropropagation from shoots and cotyledonary node segments. Plant Cell Rep 4:137-139. https://doi. org/10.1007/BF00571300

Pérez-Tornero O, Burgos L (2000) Different media requirements for micropropagation of apricot cultivars. Plant Cell Tiss Org Cult 63:133-141. https://doi.org/10.1023/A:1006430718024

Quoirin M, Lepoivre P (1977) Improved media for in vitro culture of Prunus sp. Acta Hortic 78:437-442. https://doi.org/10.17660 /ActaHortic.1977.78.54

Ramage CM, Williams RR (2002) Mineral nutrition and plant morphogenesis. Vitro Cell Dev Biol Plant 38:116-124. https://doi. org/10.1079/IVP2001269

Reed BM, DeNoma J, Wada S, Niedz R (2016) Determining optimum in vitro mineral nutrition for diverse pear germplasm using response surface methodology. Acta Hortic 1113:79-84. https://doi.org/10.17660/ActaHortic.2016.1113.11

Reed BM, Wada S, DeNoma J, Niedz RP (2013) Mineral nutrition influences physiological responses of pear in vitro. Vitro Cell Dev Biol Plant 49:699-709. https://doi.org/10.1007/s1162 7-013-9556-2

Robertson DN (2013) Modulating plant calcium for better nutrition and stress tolerance. ISRN Bot 2013:952043. https://doi. org/10.1155/2013/952043

Rugini E (1984) In vitro propagation of some olive (Olea europea sativa $\mathrm{L}$.) cultivars with different rootability, and medium development using analytical data from developing shoots and embryos. Sci Hortic 24:12-134. https://doi.org/10.1016/03044238(84)90143-2

Rugini E, Tarini P, Mari F (1986) In vitro control of shoot vitrification in almond (P. dulcis) and development of technique to eliminate apex necrosis and shoot base photo-oxidation in pistachio (Pistacia vera). HortScience 21:804

Ruiz JM, Rivero RM, López-Cantarero I, Romero L (2003) Role of $\mathrm{Ca}^{2+}$ in the metabolism of phenolic compounds in tobacco leaves (Nicotiana tabacum L.). Plant Growth Regul 41:173-177. https ://doi.org/10.1023/A:1027358423187

Ružić D, Vujović T, Libiakova G, Cerović R, Gajdošova A (2012) Micropropagation in vitro of highbush blueberry (Vaccinium corymbosum L.). J Berry Res 2:97-103. https://doi.org/10.3233/ JBR-2012-030

Sanchez MC, San-Jose MC, Ferro E, Ballester A, Vieitez AM (1997) Improving micropropagation conditions for adult-phase shoots of chestnut. J Hortic Sci 72:433-443. https://doi.org/10.1080/14620 316.1997.11515531

Santner A, Calderon-Villalobos LIA, Estelle M (2009) Plant hormones are versatile chemical regulators of plant growth. Nat Chem Biol 5:301-307. https://doi.org/10.1038/nchembio.165

Saure MC (1998) Causes of the tipburn disorder in leaves of vegetables. Sci Hortic 76:131-147. https://doi.org/10.1016/S0304 $-4238(98) 00153-8$ 
Serres R, Read P, Hackett W, Nissen P (1990) Rooting of American chestnut microcuttings. J Environ Hortic 8:86-88. https://doi. org/10.24266/0738-2898-8.2.86

Sha L, McCown BH, Peterson LA (1985) Occurrence and cause of shoot-tip necrosis in shoot cultures. J Am Soc Hortic Sci 110:631-634

Singha S, Townsend EC, Oberly GH (1990) Relationship between calcium and agar on vitrification and shoot-tip necrosis of quince (Cydonia oblonga Mill.) shoots in vitro. Plant Cell Tiss Org Cult 23:135-142. https://doi.org/10.1007/BF00035834

Srivastava A, Joshi AG (2013) Control of shoot tip necrosis in shoot cultures of Portulaca grandiflora Hook. Not Sci Biol 5:45-49. https://doi.org/10.15835/nsb519009

Strnad M, Hanuš J, Vaňek T, Kamínek M, Ballantine JA, Fussell B, Hanke DE (1997) Meta-topolin, a highly active aromatic cytokinin from poplar leaves (Populus x canadensis Moench., cv. Robusta). Phytochemistry 45:213-218. https://doi.org/10.1016/ S0031-9422(96)00816-3

Subbaiah CC, Kollipara KP, Sachs MM (2000) $\mathrm{A} \mathrm{Ca}^{2+}$-dependent cysteine protease is associated with anoxia-induced root tip death in maize. J Exp Bot 51:721-730. https://doi.org/10.1093/jexbo $\mathrm{t} / 51.345 .721$

Sudha CG, Krishnan PN, Pushpangadan P (1998) In vitro propagation of Holostemma annulare (Robx.) K. Schum., a rare medicinal plant. Vitro Cell Dev Biol Plant 34:57-63. https://doi. org/10.1007/BF02823124

Surakshitha NC, Soorianathasundaram K, Ganga M, Raveendran M (2019) Alleviating shoot tip necrosis during in vitro propagation of grape cv. Red Globe Sci Hortic 248:118-125. https://doi. org/10.1016/j.scienta.2019.01.013

Teixeira da Silva JA (2012) Is BA (6-benzyladenine) BAP (6-benzylaminopurine)? Asian Austral J Plant Sci Biotech 6:121-124

Teixeira da Silva JA (2013) The effect of ethylene inhibitors $\left(\mathrm{AgNO}_{3}\right.$, AVG), an ethylene-liberating compound (CEPA) and aeration on the formation of protocorm-like bodies of hybrid Cymbidium (Orchidaceae). Front Biol 8:606-610. https://doi.org/10.1007/ s11515-013-1283-x

Teixeira da Silva JA (2015) Negative results: negative perceptions limit their potential for increasing reproducibility. J Negative Results BioMed 14:12. https://doi.org/10.1186/s12952-015-0033-9

Teixeira da Silva JA, Dobránszki J (2013) How timing of sampling can affect the outcome of the quantitative assessment of plant organogenesis. Sci Hortic 159:59-66. https://doi.org/10.1016/j. scienta.2013.05.00

Teixeira da Silva JA, Giang DTT, Tanaka M (2006) Photoautotrophic micropropagation of Spathiphyllum. Photosynthetica 44:53-61. https://doi.org/10.1007/s11099-005-0158-z

Thakur A, Kanwar JS (2011) Effect of phase of medium, growth regulators and nutrient supplementations on in vitro shoot-tip necrosis in pear. NZ J Crop Hort Sci 39:131-140. https://doi. org/10.1080/01140671.2011.559254

Thirugnanasampandan R, Mutharaian VN, Bai VN (2009) In vitro propagation and free radical studies of Smilax zeylanica Vent. Afr J Biotechnol 8:395-400

Thomas P (2000) Microcutting leaf area, weight and position on the stock shoot influence root vigour, shoot growth and incidence of shoot tip necrosis in grape plantlets in vitro. Plant Cell Tiss Org Cult 61:189-198. https://doi.org/10.1023/A:1006425807853

Thor K (2019) Calcium-nutrient and messenger. Front Plant Sci 10:440. https://doi.org/10.3389/fpls.2019.00440

Tilkat E, Onay A, Yildirim H, Çetin Ozen H (2008) Micropropagation of mature male pistachio Pistacia vera L. J Hortic Sci Biotechnol 83:328-333. https://doi.org/10.1080/14620316.2008.11512387

Trobacher CP (2009) Ethylene and programmed cell death in plants. Botany 87:757-769. https://doi.org/10.1139/B09-041
Turland NJ, Wiersema JH, Barrie FR, Greuter W, Hawksworth DL, Herendeen PS, Knapp S, Kusber W-H, Li D-Z, Marhold K, May TW, McNeill J, Monro AM, Prado J, Price MJ, Smith (eds) (2018) International code of nomenclature for algae, fungi, and plants (Shenzhen Code) adopted by the Nineteenth International Botanical Congress Shenzhen, China, July 2017. Regnum Vegetabile 159. Koeltz Botanical Books, Glashütten. https://doi. org/10.12705/Code. 2018

van den Dries N, Giannì S, Czerednik A, Krens FA, de Klerk G-JM (2013) Flooding of the apoplast is a key factor in the development of hyperhydricity. J Exp Bot 64:5221-5230. https://doi. org/10.1093/jxb/ert315

Vanneste S, Friml J (2013) Calcium: the missing link to auxin action. Plants 2:650-675. https://doi.org/10.3390/plants2040650

Vibha JB, Shekhawat NS, Mehandru P, Dinesh R (2014) Rapid multiplication of Dalbergia sissoo Roxb.: a timber yielding tree legume through axillary shoot proliferation and ex vitro rooting. Physiol Mol Biol Plant 20:81-87. https://doi.org/10.1007/s1229 8-013-0213-3

Vieitez AM, Corredoira E, Ballester A, Muñoz F, Durán J, Ibarra M (2009) In vitro regeneration of the important North American oak species Quercus alba, Quercus bicolor and Quercus rubra. Plant Cell Tiss Org Cult 98:135-145. https://doi.org/10.1007/ s11240-009-9546-6

Vieitez AM, Sánchez C, San-José C (1989) Prevention of shoot-tip necrosis in shoot cultures of chestnut and oak. Sci Hortic 41:151159. https://doi.org/10.1016/0304-4238(89)90059-9

Wada S, Niedz RP, DeNoma J (2013) Mesos components $\left(\mathrm{CaCl}_{2}\right.$, $\mathrm{MgSO}_{4}, \mathrm{KH}_{2} \mathrm{PO}_{4}$ ) are critical for improving pear micropropagation. Vitro Cell Dev Biol Plant 49:356-365. https://doi. org/10.1007/s11627-013-9508-x

Wada S, Niedz RP, Reed BM (2015) Determining nitrate and ammonium requirements for optimal in vitro response of diverse pear species. Vitro Cell Dev Biol Plant 51:19-27. https://doi. org/10.1007/s11627-015-9662-4

Wang H, van Staden J (2001) Establishment of in vitro cultures of tree peonies. S Afr J Bot 67:358-361. https://doi.org/10.1016/S0254 $-6299(15) 31141-8$

Werbrouck SPO, Strnad M, Van Onckelen HA, Debergh PC (1996) Meta-topolin, an alternative to benzyladenine in tissue culture? Physiol Plant 98:291-297. https://doi.org/10.103 4/j.1399-3054.1996.980210.x

Wetzstein HY, Ault JR, Merkle SA (1989) Further characterization of somatic embryogenesis and plantlet regeneration in pecan (Carya illinoensis). Plant Sci 64:193-201. https://doi.org/10.1016/01689452(89)90024-1

White PJ, Broadly MR (2003) Calcium in plants. Ann Bot 92:487-511. https://doi.org/10.1093/aob/mcg164

Xing Z, Satchwell MF, Powell WA, Maynard CA (1997) Micropropagation of American chestnut: increasing rooting rate and preventing shoot-tip necrosis. Vitro Cell Dev Biol Plant 33:43-48. https ://doi.org/10.1007/s11627-997-0039-1

Ye G, McNeil DL, Conner AJ, Hill GD (2002) Multiple shoot formation in lentil (Lens culinaris) seeds. N N Z J Crop Hort Sci 30:1-8. https://doi.org/10.1080/01140671.2002.9514193

Zielińska A, Kępczyńska E (2013) Neural modeling of plant tissue cultures: a review. BioTechnologia 94:253-268. https://doi. org/10.5114/bta.2013.46419

Publisher's Note Springer Nature remains neutral with regard to jurisdictional claims in published maps and institutional affiliations. 


\section{Affiliations}

Jaime A. Teixeira da Silva ${ }^{1,2} \cdot$ Esmaeil Nezami-Alanagh $^{3,4} \cdot$ María E. Barreal $^{3}$ (1) Mafatlal M. Kher $^{5}$. Adhityo Wicaksono ${ }^{6} \mathbb{1}$ - Andrea Gulyás ${ }^{2} \cdot$ Norbert Hidvégi $^{2} \cdot$ Katalin Magyar-Tábori $^{2} \cdot$ Nóra Mendler-Drienyovszki $^{2}$. László Márton ${ }^{2} \cdot$ Mariana Landín $^{7}$ (1) Pedro Pablo Gallego ${ }^{3}$ (1) . John A. Driver ${ }^{8}$. Judit Dobránszki ${ }^{2}$

1 Present Address: Miki-cho Post Office, 3011-2, P. O. Box 7, Ikenobe, Kagawa-ken 761-0799, Japan

2 Research Institute of Nyíregyháza, IAREF, University of Debrecen, P. O. Box 12, Nyíregyháza 4400, Hungary

3 Department of Plant Biology and Soil Science, Faculty of Biology, University of Vigo, 36310 Vigo, Spain

4 Pinar Biotech. Co., Ltd., East Azarbaijan Science and Technology Park, Tabriz, Iran

5 School of Science (SOS), GSFC University, P. O. Fertilizernagar, Vadodara 391750, Gujarat, India
6 Division of Biotechnology, Generasi Biologi Indonesia (Genbinesia) Foundation, Jl. Swadaya Barat No. 4, Gresik Regency 61171, Indonesia

7 Department of Pharmacology, Pharmacy and Pharmaceutical Technology, Faculty of Pharmacy, University of Santiago, Santiago de Compostela, Spain

8 Driver Consulting Inc., 2601 Tim Bell Road, Waterford, CA 95386, USA 